\title{
Controls on seasonal patterns of maximum ecosystem carbon uptake and canopy-scale photosynthetic light response: contributions from both temperature and photoperiod
}

\section{Authors: Paul Stoy, Amy M. Trowbridge, and William L. Bauerle}

The final publication is available at Springer via http://dx.doi.org/10.1007/s11120-013-9799-0.

Stoy, Paul, Amy M. Trowbridge, and William L. Bauerle. "Controls on seasonal patterns of maximum ecosystem carbon uptake and canopy-scale photosynthetic light response:

contributions from both temperature and photoperiod." Photosynthesis Research 119, no. 1-2 (2014): 49-64. 


\title{
Controls on seasonal patterns of maximum ecosystem carbon uptake and canopy-scale photosynthetic light response: contributions from both temperature and photoperiod
}

\author{
Paul C. Stoy • Amy M. Trowbridge • \\ William L. Bauerle
}

\begin{abstract}
Most models of photosynthetic activity assume that temperature is the dominant control over physiological processes. Recent studies have found, however, that photoperiod is a better descriptor than temperature of the seasonal variability of photosynthetic physiology at the leaf scale. Incorporating photoperiodic control into global models consequently improves their representation of the seasonality and magnitude of atmospheric $\mathrm{CO}_{2}$ concentration. The role of photoperiod versus that of temperature in controlling the seasonal variability of photosynthetic function at the canopy scale remains unexplored. We quantified the seasonal variability of ecosystem-level light response curves using nearly 400 site years of eddy covariance data from over eighty Free Fair-Use sites in the FLUXNET database. Model parameters describing maximum canopy $\mathrm{CO}_{2}$ uptake and the initial slope of the light response curve peaked after peak temperature in about $2 / 3$ of site years examined, emphasizing the important role of temperature in controlling seasonal photosynthetic function. Akaike's Information Criterion analyses indicated that photoperiod should be included in models of seasonal parameter variability in over $90 \%$ of the site years investigated here, demonstrating that photoperiod also plays an important role
\end{abstract}

P. C. Stoy $(\bowtie) \cdot$ A. M. Trowbridge

Department of Land Resources and Environmental Sciences,

Montana State University, Bozeman, MT 59717, USA

e-mail: paul.stoy@montana.edu

W. L. Bauerle

Department of Horticulture and Landscape Architecture,

Colorado State University, Fort Collins, CO 80523, USA

W. L. Bauerle

Graduate Degree Program in Ecology, Colorado State

University, Fort Collins, CO 80523, USA in controlling seasonal photosynthetic function. We also performed a Granger causality analysis on both gross ecosystem productivity (GEP) and GEP normalized by photosynthetic photon flux density $\left(\mathrm{GEP}_{n}\right)$. While photoperiod Granger-caused GEP and $\mathrm{GEP}_{n}$ in 99 and $92 \%$ of all site years, respectively, air temperature Granger-caused GEP in a mere $32 \%$ of site years but Granger-caused $\mathrm{GEP}_{n}$ in $81 \%$ of all site years. Results demonstrate that incorporating photoperiod may be a logical step toward improving models of ecosystem carbon uptake, but not at the expense of including enzyme kinetic-based temperature constraints on canopy-scale photosynthesis.

Keywords Eddy covariance - Granger causality · Gross ecosystem productivity - Light response curve . Net ecosystem exchange $\cdot$ Seasonal variability
Abbreviations
AIC Akaike's Information Criterion
C-LAMP Carbon Land Model Intercomparison Project
CLM Community Land Model
DOY Day of year
GEP Gross ecosystem productivity
$\mathrm{GPP}_{n} \quad$ Gross ecosystem productivity normalized by
GPP $\quad$ Ghotosynthetic photon flux
HSD (Tukey's) Honestly Significant Difference test
$J_{\max }$ Rate of photosynthetic electron flow at light saturation
$L \quad$ Maximum value of the likelihood function
$L_{\text {Day }} \quad$ Day length
$M \quad$ Linear model
$N \quad$ Number of parameters
$N \quad$ Number of instances
NEE Net ecosystem exchange 


\begin{tabular}{|c|c|}
\hline PPFD & Photosynthetic photon flux density \\
\hline $\mathrm{RE}$ & Ecosystem respiration \\
\hline$T_{\mathrm{a}}$ & Air temperature \\
\hline$V_{\mathrm{c}, \max }$ & Maximum carboxylation capacity \\
\hline$\alpha$ & Initial slope of the light response curve \\
\hline$\beta$ & Net ecosystem exchange at light saturation \\
\hline$\gamma$ & $\begin{array}{l}\text { Ecosystem respiration calculated as the intercept } \\
\text { of the light response curve }\end{array}$ \\
\hline$\theta_{N}$ & $\begin{array}{l}\text { Degree of curvature of the non-rectangular } \\
\text { hyperbola }\end{array}$ \\
\hline$M$ & Referring to the Mitscherlich model \\
\hline $\max$ & $\begin{array}{l}\text { Referring to the maximum seasonal value } \\
\text { calculated using a second-order polynomial }\end{array}$ \\
\hline$N$ & Referring to the non-rectangular hyperbola \\
\hline$p$ & $\begin{array}{l}\text { Referring to a light response curve parameter } \\
\text { or combination of parameters }\end{array}$ \\
\hline
\end{tabular}

\section{Introduction}

Chemical reactions, including those mediated by biological processes, are dependent on temperature. At the same time, organisms exhibit control over temporal aspects of reaction rates, the most familiar of which are the ca. $24 \mathrm{~h}$ periodicities known as circadian rhythms that were described for stomatal conductance as early as Darwin (1898) and for photosynthesis as early as Hastings et al. (1961) (see Webb 2003). Recent studies have even found evidence of circadian patterns in carbon uptake at the ecosystem scale (de Dios et al. 2012), suggesting that models of canopy photosynthesis may benefit by simply including time as an independent variable.

The broader study of temporal changes in organismal function is known as chronobiology, and botanical examples include the seasonal variability in carbon and nutrient uptake and allocation. Despite chronobiological control over many aspects of plant function, the most common models of photosynthesis include parameters that are constant or are a function of temperature, leaf nitrogen concentration, and other factors (Farquhar et al. 1980), rather than photoperiod. These formulations follow from the fundamental rate laws of enzyme kinetics, but may be incomplete descriptions of the seasonality of photosynthesis if chronobiological factors are also at play.

Recent research has shown that photoperiod (here abbreviated $L_{\text {Day }}$ for day length) is a better descriptor of the seasonal patterns of leaf-level photosynthetic activity than is temperature (Bauerle et al. 2012). Applying these findings to the CLM global-scale terrestrial carbon cycle model improved its ability to replicate the observed global seasonal pattern and magnitude of atmospheric $\mathrm{CO}_{2}$ concentration (Bauerle et al. 2012; Bonan et al. 2011). These results suggest that $L_{\text {Day }}$ may improve models of gross ecosystem productivity (GEP) at the canopy scale (Groenendijk et al. 2011). However, controls over the seasonal pattern of GEP remain unclear because of the multiple mechanisms that determine canopy photosynthesis. For example, leaf area index varies over the course of the season, even in tropical canopies (van Schaik et al. 1993; Wright and van Schaik 1994). Longer photoperiods correspond to smaller minimum zenith angles and greater canopy penetration of direct solar radiation (Song et al. 2009). Leaf age and $N$ allocation also influence the seasonal pattern of photosynthetic parameters and photosynthetic rates (Wilson et al. 2000; Reich et al. 1991), and incorporating this information into ecosystem models improves their ability to capture the seasonal dynamics and magnitude of photosynthetic uptake (Wilson et al. 2001). A number of mechanisms are thus responsible for seasonal variability of canopy photosynthesis, and it is unclear if simply adding $L_{\text {Day }}$ as an independent variable will improve model skill.

Incorporating canopy structure and nutrient allocation into models of canopy photosynthesis remains a challenge because it is difficult to observe the timing and magnitude of canopy development and photosynthetic capacity at plot, regional, and global scales (Fisher et al. 2007; Grace et al. 2007; Tian et al. 2002). These challenges remain despite recent improvements in our ability to apply remote sensing observations to quantify canopy function (Ryu et al. 2011; Asner 1998), and remote sensing observations, like all observations, contain important uncertainties (Foody and Atkinson 2006). Uncertainties in the independent variables of an ecological model introduce the well-known "errors in x" problem (Chesher 1991; Fuller 1987) (also known as "regression dilution" or "attenuation"), which add bias error to the dependent variable, in our case GEP. Time, for all intents and purposes, is without uncertainty for ecological applications, excluding human error in timekeeping. If $L_{\text {Day }}$ can be used as an explanatory variable for photosynthesis models at the canopy scale, following the findings of Bauerle et al. (2012) at the leaf and global scales, a variable that is uniquely nearly error-free (at least for the purposes of ecological studies) can be used to improve ecosystem models.

To explore the role of $L_{\text {Day }}$ in controlling seasonal variability in GEP and canopy-scale photosynthetic function, we adopt a data-intensive approach (Gray 2009) to explore patterns in large ecological datasets (Hunt et al. 2009). We examined 385 site years of eddy covariance-measured net ecosystem exchange (NEE) and estimated GEP from 81 research sites to test if adding time via $L_{\text {Day }}$ in addition to temperature improves model prediction of maximum ecosystem-scale carbon uptake and the initial slope of the light response curve. We chose to investigate the parameters of simple light response curves to avoid introducing 
uncertainties from other variables (e.g., leaf area index) used to infer Farquhar et al. (1980) model parameters (e.g., $\left.V_{\mathrm{c}, \max }\right)$ from eddy covariance data. Maximum ecosystemscale carbon uptake was chosen for this analysis because of its importance in determining the magnitude of GEP across ecosystem types (Desai et al. 2008a). Seasonality of the initial slope of the light response curve was explored because the GEP-light response relationship was identified by a recent multi-site and multi-model synthesis as a primary source of model bias (Schaefer et al. 2012). Specifically, we model carbon uptake as a function of photosynthetic photon flux density (PPFD) for over 140,000 days of half-hourly (or hourly) eddy covariance data and use information criteria analyses and a well-established econometric analysis, Granger Causality (Granger 1969; Detto et al. 2012), to determine if information in $L_{\text {Day }}$, air temperature $\left(T_{\mathrm{a}}\right)$, or a combination of both better explain seasonal patterns of GEP and canopy light response curve parameters. We also test if the day of year (DOY) on which photosynthetic parameters reach their seasonal maximum (DOY max,$p$ ) occurs before or after that of temperature (DOY $\mathrm{max}_{\mathrm{ma}}$ ) and $L_{\text {Day }}$ (i.e., the summer solstice, DOY 172 during non leap-years) to explore how environmental variables contribute causal information to seasonal patterns of parameter variability. We further explore how climate zones and vegetation clas-

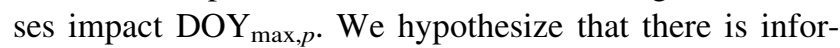
mation in the $L_{\text {Day }}$ time series that helps explain seasonal variability in canopy-level photosynthetic function following Bauerle et al. (2012).

\section{Methods}

We first describe the eddy covariance and meteorological data used here, followed by a description of the light response curve analysis including the calculation of the seasonal maxima of light response curve parameters. We then describe the statistical analyses, information criteria analyses, and Granger causality.

\section{Eddy covariance}

We analyzed patterns of NEE, GEP, $T_{\mathrm{a}}$, and $L_{\text {Day }}$ using 385 site years of eddy covariance flux observations from 81 forest and shrub-dominated sites designated as Free Fair-Use in the FLUXNET database (Fig. 1; Tables 1, 2). Grasslands and

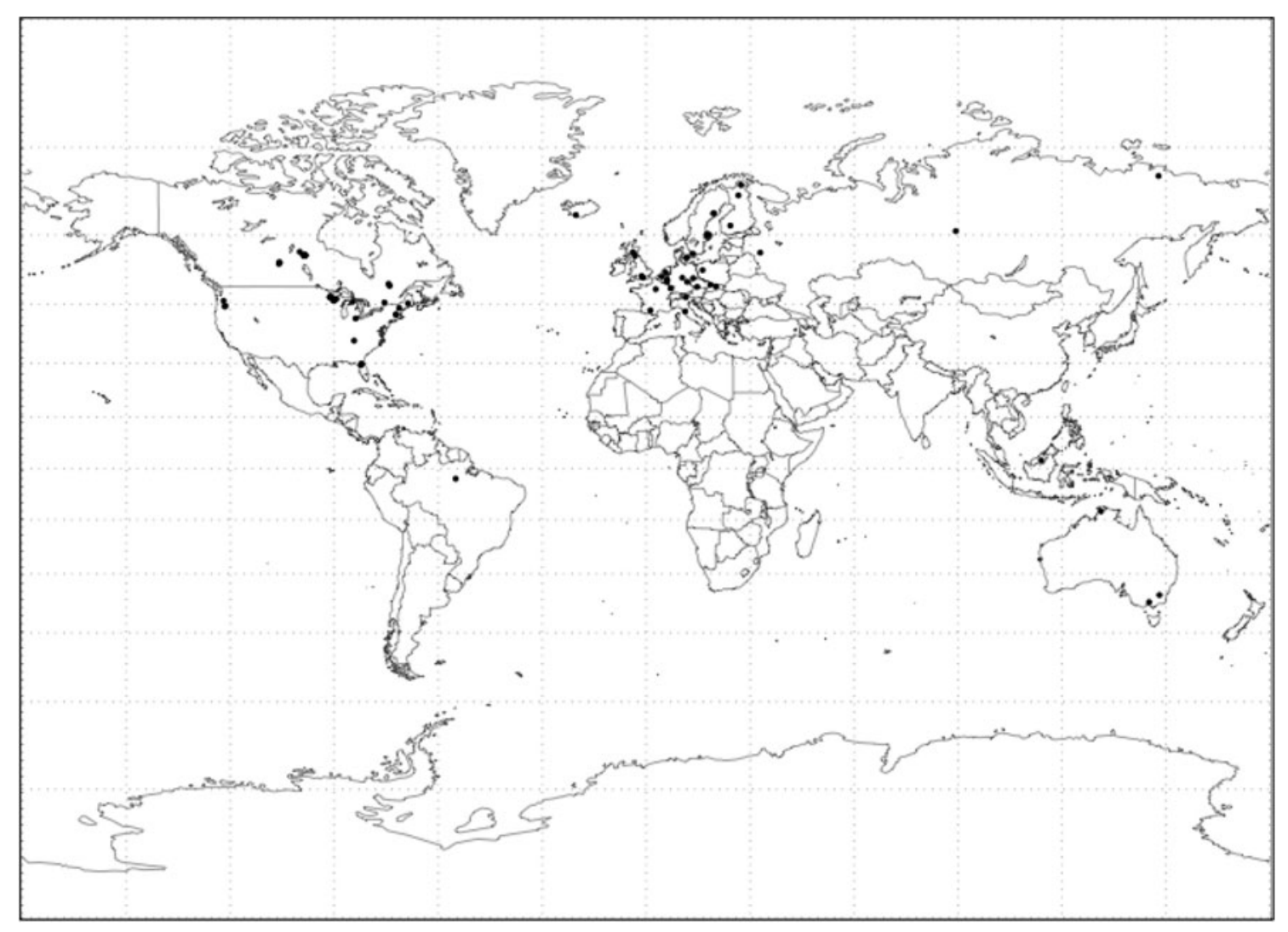

Fig. 1 A global map of the Free Fair-Use eddy covariance research sites in the FLUXNET database, excluding sites in Dry (Semi-Arid and Arid) and Mediterranean climates where water availability is likely a dominant control over seasonal patterns of canopy photosynthesis, and grassland and crop ecosystems where ecosystem management is likely a dominant control over seasonal patterns of canopy photosynthesis (see Table 1) 
Table 1 Vegetation (Veg.), climate (Clim.), years of available data (Years), latitude (Lat.), and longitude (Long.) for the 81 FLUXNET sites and 385 site years in the Free Fair-Use database analyzed here

\begin{tabular}{|c|c|c|c|c|c|c|}
\hline Site & Veg. $^{\text {a }}$ & Clim. $^{\mathrm{b}}$ & Years & Lat. & Long. & Reference \\
\hline AUFog & WET & TR & 2006-2007 & -12.5425 & 131.307 & Guerschman et al. (2009) \\
\hline AUTum & $\mathrm{EBF}$ & $\mathrm{T}$ & 2001-2006 & -35.6557 & 148.152 & Finnigan and Leuning (2000) \\
\hline AUWac & EBF & $\mathrm{T}$ & 2005-2006 & -37.429 & 145.187 & Beringer et al. (2006) \\
\hline BEBra & MF & $\mathrm{T}$ & 1997-2006 [1999, 2003] & 51.3092 & 4.52056 & de Pury and Ceulemans (1997) \\
\hline BEJal & MF & $\mathrm{T}$ & 2006 & 50.5639 & 6.07333 & - \\
\hline BEVie & MF & $\mathrm{T}$ & 1996-2006 & 50.3055 & 5.99683 & Aubinet et al. (2001) \\
\hline $\mathrm{BRSa} 3$ & EBF & TR & $2000-2003$ & -3.01803 & -54.9714 & Saleska et al. (2003) \\
\hline CAMan & ENF & $\mathrm{B}$ & 1994-2003 [1996] & 55.8796 & -98.4808 & Sellers et al. (1995) \\
\hline CAMer & WET & $\mathrm{TC}$ & $1998-2005$ & 45.4094 & -75.5186 & Lafleur et al. (2003) \\
\hline CANS1 & ENF & $\mathrm{B}$ & 2002-2005 & 55.8792 & -98.4839 & Goulden et al. (2006) \\
\hline CANS2 & ENF & $\mathrm{B}$ & 2001-2005 & 55.9058 & -98.5247 & Goulden et al. (2006) \\
\hline CANS3 & ENF & $\mathrm{B}$ & $2001-2005$ & 55.9117 & -98.3822 & Goulden et al. (2006) \\
\hline CANS4 & ENF & $\mathrm{B}$ & 2002-2004 & 55.9117 & -98.3822 & Goulden et al. (2006) \\
\hline CANS5 & ENF & $\mathrm{B}$ & $2001-2005$ & 55.8631 & -98.4850 & Goulden et al. (2006) \\
\hline CANS6 & $\mathrm{OSH}$ & $\mathrm{B}$ & $2001-2005$ & 55.9167 & -98.9644 & Goulden et al. (2006) \\
\hline CANS7 & $\mathrm{OSH}$ & $\mathrm{B}$ & $2002-2005$ & 56.6358 & -99.9483 & Goulden et al. (2006) \\
\hline CAQcu & ENF & $\mathrm{B}$ & 2001-2006 & 49.2671 & -74.0365 & Giasson et al. (2006) \\
\hline CAQfo & ENF & $\mathrm{B}$ & $2003-2006$ & 49.6925 & -74.3421 & Bergeron et al. (2007) \\
\hline CASF1 & ENF & $\mathrm{B}$ & $2003-2005$ & 54.4850 & -105.818 & Amiro et al. (2006) \\
\hline CASF2 & ENF & $\mathrm{B}$ & $2003-2005$ & 54.2539 & -105.878 & Rayment and Jarvis (1999) \\
\hline CASF3 & ENF & $\mathrm{B}$ & $2003-2005$ & 54.0916 & -106.005 & Rayment and Jarvis (1999) \\
\hline CZBK1 & ENF & $\mathrm{TC}$ & $2000-2006$ & 49.5026 & 18.5384 & Havrankova and Sedlak (2004) \\
\hline CZwet & WET & $\mathrm{T}$ & 2006 & 49.0250 & 14.7720 & Dušek et al. (2009) \\
\hline DEBay & ENF & $\mathrm{T}$ & 1997-1999 & 50.1419 & 11.8669 & Valentini et al. (2000) \\
\hline DEHai & DBF & $\mathrm{T}$ & 2001-2006 & 51.0793 & 10.452 & Knohl et al. (2003) \\
\hline DETha & ENF & $\mathrm{T}$ & 1996-2006 & 50.9636 & 13.5669 & Bernhofer et al. (2003) \\
\hline DEWet & ENF & $\mathrm{T}$ & 2002-2006 & 50.4535 & 11.4575 & Anthoni et al. (2004) \\
\hline DKSor & DBF & $\mathrm{T}$ & 1996-2006 & 55.4869 & 11.6458 & Pilegaard et al. (2001) \\
\hline FIHyy & ENF & $\mathrm{B}$ & 1996-2006 & 61.8474 & 24.2948 & Suni et al. (2003) \\
\hline FIKaa & WET & $\mathrm{B}$ & 2000-2006 & 69.1407 & 27.295 & Aurela et al. (2002) \\
\hline FISod & ENF & $\mathrm{B}$ & 2000-2006 & 67.3619 & 26.6378 & Thum et al. (2007) \\
\hline FRFon & $\mathrm{DBF}$ & $\mathrm{T}$ & 2005-2006 & 48.4763 & 2.7801 & Le Maire et al. (2005) \\
\hline FRHes & $\mathrm{DBF}$ & $\mathrm{T}$ & 1997-2006 & 48.6742 & 7.06462 & Granier et al. (2000) \\
\hline FRLBr & ENF & $\mathrm{T}$ & 1996-2006 [1999] & 44.7171 & -0.7693 & Berbigier et al. (2001) \\
\hline IDPag & $\mathrm{EBF}$ & $\mathrm{TR}$ & 2002-2003 & 2.3450 & 114.0360 & Hirano et al. (2007) \\
\hline ISGun & $\mathrm{DBF}$ & $\mathrm{T}$ & 1996-1998 & 63.8333 & -20.2167 & Aradóttir et al. (1997) \\
\hline ITLav & ENF & $\mathrm{T}$ & 2000-2006 [2003, 2005] & 45.9553 & 11.2812 & Cescatti and Marcolla (2004) \\
\hline ITRen & ENF & $\mathrm{T}$ & 1999-2006 & 46.5878 & 11.4347 & Marcolla et al. (2003) \\
\hline NLLoo & ENF & $\mathrm{T}$ & 1996-2006 & 52.1679 & 5.74396 & Dolman et al. (2002) \\
\hline PLWet & WET & $\mathrm{T}$ & 2004-2005 & 52.7622 & 16.3094 & Chojnicki et al. (2007) \\
\hline RUCok & OSH & A & 2003-2005 & 70.6167 & 147.8830 & van der Molen et al. (2007) \\
\hline RUFyo & ENF & $\mathrm{TC}$ & 1998-2004 & 56.46167 & 32.92389 & Kurbatova et al. (2008) \\
\hline RUZot & ENF & $\mathrm{B}$ & 2002-2004 & 60.8008 & 89.3508 & Kurbatova et al. (2002) \\
\hline SEDeg & WET & $\mathrm{B}$ & 2001-2005 & 64.1833 & 19.5500 & Sagerfors et al. (2008) \\
\hline SEFaj & WET & $\mathrm{T}$ & 2005-2006 & 56.2655 & 13.5535 & Lund et al. (2007) \\
\hline SEFla & ENF & $\mathrm{B}$ & 1996-2002 [1999] & 64.1128 & 19.4569 & Valentini et al. (2000) \\
\hline SENor & ENF & $\mathrm{TC}$ & 1996-2005 [2000-02, 2004] & 60.0865 & 17.4795 & Lagergren et al. (2008) \\
\hline SESk1 & ENF & $\mathrm{TC}$ & 2005 & 60.125 & 17.9181 & Gioli et al. (2004) \\
\hline
\end{tabular}


Table 1 continued

\begin{tabular}{|c|c|c|c|c|c|c|}
\hline Site & Veg. $^{a}$ & Clim. $^{\mathrm{b}}$ & Years & Lat. & Long. & Reference \\
\hline SESk2 & ENF & $\mathrm{TC}$ & 2004-2005 & 60.12967 & 17.8401 & Lindroth et al. (2008b) \\
\hline SKTat & ENF & $\mathrm{TC}$ & 2005 & 49.1208 & 20.1635 & Matese et al. (2008) \\
\hline UKAMo & WET & $\mathrm{T}$ & 2005 & 55.7917 & -3.23889 & Hargreaves et al. (2003) \\
\hline UKGri & ENF & $\mathrm{T}$ & 1997-2006 [1999, 2002-2004] & 56.60722 & -3.79806 & Medlyn et al. (2005) \\
\hline UKHam & DBF & $\mathrm{T}$ & 2004-2005 & 51.1208 & -0.8608 & Wilkinson et al. (2012) \\
\hline UKPL3 & DBF & $\mathrm{T}$ & $2005-2006$ & 51.4500 & -1.26667 & Herbst et al. (2008) \\
\hline USBar & DBF & $\mathrm{TC}$ & 2004-2005 & 44.0646 & -71.2881 & Richardson et al. (2007a) \\
\hline USHa1 & DBF & $\mathrm{TC}$ & 1991-2006 & 42.5378 & -72.1715 & Wofsy et al. (1993) \\
\hline USHo1 & ENF & $\mathrm{TC}$ & 1996-2004 & 45.2041 & -68.7402 & Hollinger et al. (1999) \\
\hline USHo2 & ENF & $\mathrm{TC}$ & 1999-2004 & 45.2091 & -68.7470 & Thornton et al. (2002) \\
\hline USLos & $\mathrm{DBF}$ & $\mathrm{TC}$ & 2001-2005 & 46.0827 & -89.9792 & Desai et al. (2008b) \\
\hline USMMS & $\mathrm{DBF}$ & $\mathrm{T}$ & $2001-2005$ & 39.3231 & -86.4131 & Schmid et al. (2000) \\
\hline USMOz & $\mathrm{DBF}$ & $\mathrm{T}$ & 2004-2006 & 38.7441 & -92.2000 & Gu et al. (2006) \\
\hline USOho & $\mathrm{DBF}$ & $\mathrm{TC}$ & 2004-2005 & 41.5545 & -83.8438 & DeForest et al. (2006) \\
\hline USPFa & MF & $\mathrm{TC}$ & 1996-2003 [1998, 2001-2002] & 45.9459 & -90.2723 & Berger et al. (2001) \\
\hline USSP1 & ENF & $\mathrm{S}$ & 2000-2001, 2005 & 29.7381 & -82.2188 & Clark et al. (1999) \\
\hline USSP2 & ENF & $\mathrm{S}$ & 1998-2004 & 29.7648 & -82.2448 & Clark et al. (1999) \\
\hline USSP3 & ENF & $\mathrm{S}$ & 1999-2004 & 29.7548 & -82.1633 & Clark et al. (1999) \\
\hline USSP4 & ENF & $\mathrm{S}$ & 1998 & 29.8028 & -82.2031 & Fang et al. (1998) \\
\hline USSyv & $\mathrm{MF}$ & $\mathrm{TC}$ & 2002-2006 & 46.242 & -89.3477 & Desai et al. (2005) \\
\hline USUMB & DBF & $\mathrm{TC}$ & 1999-2003 & 45.5598 & -84.7138 & Curtis et al. (2002) \\
\hline USWBW & $\mathrm{DBF}$ & $\mathrm{S}$ & 1995-1999 & 35.9588 & -84.2874 & Verma et al. (1986) \\
\hline USWCr & $\mathrm{DBF}$ & $\mathrm{TC}$ & 1999-2006 & 45.8059 & -90.0799 & Cook et al. (2004) \\
\hline USWi0 & ENF & $\mathrm{TC}$ & 2002 & 46.6188 & -91.0814 & Desai et al. (2008a) \\
\hline USWi1 & $\mathrm{DBF}$ & $\mathrm{TC}$ & 2003 & 46.7305 & -91.2329 & Noormets et al. (2007) \\
\hline USWi2 & ENF & $\mathrm{TC}$ & 2003 & 46.6869 & -91.1528 & Noormets et al. (2007) \\
\hline USWi4 & ENF & $\mathrm{TC}$ & 2002-2005 & 46.7393 & -91.1663 & Noormets et al. (2007) \\
\hline USWi5 & ENF & $\mathrm{TC}$ & 2004 & 46.6531 & -91.0858 & Noormets et al. (2007) \\
\hline USWi6 & $\mathrm{OSH}$ & $\mathrm{TC}$ & 2002 & 46.6249 & -91.2982 & Noormets et al. (2007) \\
\hline USWi7 & $\mathrm{OSH}$ & $\mathrm{TC}$ & 2005 & 46.6491 & -91.0693 & Noormets et al. (2007) \\
\hline USWi8 & DBF & $\mathrm{TC}$ & 2002 & 46.7223 & -91.2524 & Noormets et al. (2007) \\
\hline USWi9 & ENF & $\mathrm{TC}$ & 2004-2005 & 46.6188 & -91.0813 & Noormets et al. (2007) \\
\hline USWrc & ENF & $\mathrm{T}$ & 1998-2006 [2003] & 45.8205 & -121.952 & Chen et al. (2002) \\
\hline
\end{tabular}

Square brackets indicate years of observations that were not available for analysis

${ }^{a}$ Veg. vegetation following the International Geosphere-Biosphere Programme (IGBP) classification. DBF deciduous broadleaf forest, ENF evergreen needleleaf forest, $M F$ mixed forest, $O S H$ open shrubland, WET wetland

${ }^{\mathrm{b}}$ Climate group following the Köppen-Geiger classification scheme. $A$ arctic, $B$ boreal, $S$ subtropical, $T$ temperate, $T C$ temperate continental, $T R$ tropical

croplands that are likely to experience substantial anthropogenic management were excluded from the analysis, as were ecosystems from Mediterranean and dry (arid and semi-arid) climate classifications whose seasonal patterns of ecological function are likely constrained by water availability (Ryu et al. 2008).

Eddy covariance is a standard methodology for measuring ecosystem-level fluxes of carbon, water, and energy (Baldocchi et al. 2001; Aubinet et al. 2000). Briefly, the eddy covariance technique measures the turbulent exchange of sensible heat, latent heat (i.e., evapotranspiration), and trace gases including $\mathrm{CO}_{2}$ between the biosphere and atmosphere. It does so by coupling high frequency (usually 10 to $20 \mathrm{~Hz}$ ) measurements of the three-dimensional wind velocity with trace gas and water vapor concentration measurements from a fast-response infrared gas analyzer. Surface-atmosphere exchange of mass and energy is well-represented by the turbulent flux across a plane in the boundary layer above the surface plus any changes in mass and energy storage underneath the 
Table 2 Summary table of the number of site years of eddy covariance data available per vegetation and climate class in the Free Fair-Use FLUXNET database, excluding Dry climate classes and Crop, Grassland, and Savanna vegetation classes

\begin{tabular}{lrrlrlrr}
\hline & T & TC & TR & B & A & S & Sum \\
\hline DBF & 46 & 40 & 0 & 0 & 0 & 5 & 91 \\
EBF & 9 & 0 & 6 & 0 & 0 & 0 & 15 \\
ENF & 65 & 48 & 0 & 76 & 0 & 17 & 206 \\
MF & 20 & 10 & 0 & 0 & 0 & 0 & 30 \\
OSH & 0 & 2 & 0 & 9 & 3 & 0 & 14 \\
WET & 7 & 8 & 1 & 13 & 0 & 0 & 29 \\
Sum & 148 & 108 & 7 & 98 & 3 & 22 & 385 \\
\hline
\end{tabular}

Vegetation following the International Geosphere-Biosphere Programme (IGBP) classification. $D B F$ deciduous broadleaf forest, $E N F$ evergreen needleleaf forest, $M F$ mixed forest, $O S H$ open shrubland, WET wetland

Climate group following the Köppen-Geiger classification scheme. A arctic, $B$ boreal, $S$ subtropical, $T$ temperate, $T C$ temperate continental, $T R$ tropical

sensor system during conditions of near-neutral atmospheric stability (Aubinet et al. 2000; Foken et al. 2012). The magnitude and direction of surface-atmosphere mass and energy exchange is typically calculated over a halfhourly or hourly time step, and eddy covariance measurement systems are often run for multiple years or decades (e.g., Urbanski et al. 2007; Baldocchi 2008) such that patterns of ecosystem metabolism across diurnal, seasonal, annual, and interannual time scales can be quantified (Richardson et al. 2007b; Stoy et al. 2009; Desai 2010).

Eddy covariance measures NEE rather than GEP (see Goulden et al. 1997, for a discussion of the distinction between GEP and gross primary productivity, GPP). GEP is often estimated as the difference between NEE and a model for ecosystem respiration (RE) that is parameterized using observations of NEE at night when GEP is negligible in $\mathrm{C}_{3}$ and $\mathrm{C}_{4}$-dominated ecosystems following the definition equation:

$\mathrm{NEE}=\mathrm{GEP}+\mathrm{RE}$

Carbon uptake by the biosphere is denoted as negative following the atmospheric convention used by most eddy covariance studies. Here we adopt the biological convention and denote ecosystem carbon uptake as positive such that GEP is defined as positive for consistency with studies of plant physiology.

\section{Light response curves}

Most RE models used for the purposes of estimating GEP from EC observations use $T_{\mathrm{a}}$ (or soil temperature) as an independent variable (Reichstein et al. 2005; Reichstein et al. 2012), which would add a temperature-based model into our estimate of GEP (Eq. 1). To avoid contaminating our GEP estimates with an uncertain temperature signal, we used measured (i.e., not gap-filled) eddy covariance data collected during both day time and night time and estimated RE as the zero intercept of a light response curve (Lasslop et al. 2010; Lee et al. 1999), an approach that was found to better-match biometric estimates of ecosystem carbon uptake across different ecosystem types than models based on the night time $T_{\mathrm{a}}-\mathrm{RE}$ relationship (Stoy et al. 2006). We explore parameters from the Mitscherlich model (Lindroth et al. 2008a; Aubinet et al. 2001):

$\mathrm{NEE}=\left(\beta_{M}+\gamma_{M}\right)\left(1-\exp \left(\frac{-\alpha_{M} \text { PPFD }}{\beta_{M}+\gamma_{M}}\right)\right)-\gamma_{M}$

and the non-rectangular hyperbola (Gilmanov et al. 2003; Lambers et al. 2000):

$$
\begin{aligned}
\mathrm{NEE}= & \frac{1}{2 \theta_{N}}{ } \mathrm{PPFD}+\beta_{N} \\
& \left.-\sqrt{\left(\alpha_{N} \mathrm{PPFD}+\beta_{N}\right)^{2}-4 \alpha_{N} \beta_{N} \theta_{N} \mathrm{PPFD}}\right)-\gamma_{N}
\end{aligned}
$$

where $\alpha$ is the initial slope of the light response curve (also called apparent quantum yield), $\beta$ is NEE at light saturation, $\gamma$ represents RE, and $\theta$ is the degree of curvature in the non-rectangular hyperbola. Following equation $1, \beta+\gamma$ represents GEP at light saturation, and we also examine $\beta$ (i.e., NEE at light saturation) for completeness. $\beta$ is related to the rate of photosynthetic electron flow at light saturation, $J_{\max }$, of the Farquhar et al. (1980) photosynthesis model (Lambers et al. 2000).

Mitscherlich model parameters were chosen to avoid overestimates of $\beta$ that can result from parameterizing the simple rectangular hyperbola (Reichstein et al. 2012). The non-rectangular hyperbola (Eq. 3) can further improve estimates of $\beta$ and also $\alpha$ (Gilmanov et al. 2003), but parameter optimization routines often suffer from lack of convergence when fitting the four-parameter non-rectangular hyperbola to eddy covariance data (Stoy et al. 2006). By exploring both models, we constrain our estimates of $\alpha, \beta$, and $\beta+\gamma$ for a more conservative interpretation of their variability.

To quantify seasonal patterns of $\alpha, \beta$, and $\beta+\gamma$ from hundreds of site years of observations, we fit the parameters of Eqs. 2 and 3 with a nonlinear least squares algorithm (MATLAB, Mathworks, Natick MA) using data from a seven-day moving window centered about each DOY for each site year as demonstrated in Fig. 2. Corresponding parameter values for the models in Fig. 2 are listed in Table 3. The seven-day window was chosen to obtain a sufficient number of data points to fit the parameters of Eqs. 2 and 3. Periods for which the parameter estimation routine did not converge were excluded from the analysis, 


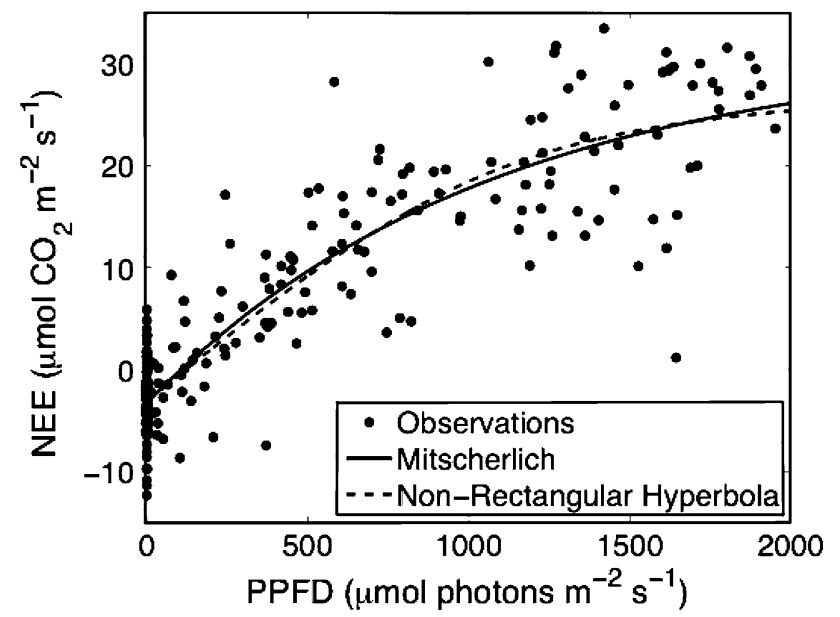

Fig. 2 Eddy covariance-measured NEE using the physiological convention in which flux from atmosphere to biosphere is denoted as positive as a function of photosynthetic photon flux density $(P P F D)$ for the period between day of year (DOY) 185 and 191 (i.e., July 4-10), 1999, at the Walker Branch Watershed (US-WBW) site in eastern TN (Table 1). Corresponding parameters for the Mitscherlich (Eq. 2) and non-rectangular hyperbola (Eq. 3) are presented in Table 3

Table 3 Parameter values with $95 \%$ confidence intervals $(C I)$ for the light response curves (Eqs. 2, 3) demonstrated in Fig. 2, corresponding to the period between day of year (DOY) 185 and 191 (i.e., July 4-10), 1999, at the Walker Branch Watershed (US-WBW) site in eastern Tennessee, USA (Table 1)

\begin{tabular}{lcl}
\hline Parameter & Value $\pm \mathrm{CI}$ & Units \\
\hline$\alpha_{M}$ & $0.032 \pm 0.0073$ & $\mu \mathrm{mol} \mathrm{CO} 2 \mu \mathrm{mol} \mathrm{photons}^{-1}$ \\
$\beta_{M}$ & $31.6 \pm 6.7$ & $\mu \mathrm{mol} \mathrm{CO} \mathrm{m}^{-2} \mathrm{~s}^{-1}$ \\
$\gamma_{M}$ & $3.3 \pm 1.1$ & $\mu \mathrm{mol} \mathrm{CO} \mathrm{m}^{-2} \mathrm{~s}^{-1}$ \\
$\alpha_{N}$ & $0.026 \pm 0.0081$ & $\mu \mathrm{mol} \mathrm{CO} \mu \mathrm{mol} \mathrm{photons}^{-1}$ \\
$\beta_{N}$ & $32.0 \pm 11$ & $\mu \mathrm{mol} \mathrm{CO} \mathrm{m}^{-2} \mathrm{~s}^{-1}$ \\
$\theta_{N}$ & $0.90 \pm 0.30$ & \\
$\gamma_{N}$ & $3.1 \pm 1.1$ & $\mu \mathrm{mol} \mathrm{CO}_{2} \mathrm{~m}^{-2} \mathrm{~s}^{-1}$ \\
\hline
\end{tabular}

as were days for which the estimated $\beta$ or $\gamma$ parameters exceeded $50 \mu \mathrm{mol} \mathrm{CO}_{2} \mathrm{~m}^{-2} \mathrm{~s}^{-1}$, and for which the estimated $\alpha$ parameter exceeded $0.2 \mu \mathrm{mol} \mathrm{CO}_{2} \mu \mathrm{mol}$ photons $^{-1}$. NEE observations whose magnitude exceeded $50 \mu \mathrm{mol} \mathrm{CO}_{2} \mathrm{~m}^{-2} \mathrm{~s}^{-1}$ occurred very infrequently in the dataset, and likely represent erroneous observations that eluded standard filters (Papale et al. 2006).

Seasonal variability of light response curve parameters

We also used nonlinear least squares to fit the parameters of a second-order polynomial with associated uncertainty estimates in order to calculate the DOY for which $T_{\mathrm{a}}, \alpha, \beta$, and $\beta+\gamma$ are at their seasonal maximum using: $p_{1} \mathrm{DOY}^{2}+p_{2} \mathrm{DOY}+p_{3}$

where the DOY associated with the maximum parameter values $\left(\mathrm{DOY}_{\max , p}\right)$ and temperature $\left(\mathrm{DOY}_{\max , \mathrm{T}_{\mathrm{a}}}\right)$ is equal to the vertical axis of symmetry for a parabola, $-p_{2} / 2 p_{1}$.

Site years for which less than 300 days of data were measured were excluded from the analysis. An example of the seasonal variability of $L_{\text {Day }}, T_{\mathrm{a}}$, and $\beta_{M}$ for a single site year is demonstrated in Fig. 3. $L_{\text {Day }}$ was calculated following Campbell and Norman (1998) for each site year using eddy covariance tower coordinates.

Statistical analysis

To quantify if DOY $\mathrm{max}, p_{\text {was }}$ wignificantly different among vegetation and climate classes, we performed individual one-way ANOVAs for the seasonal patterns of $\alpha, \beta$, and $\beta+\gamma$ parameters of the Mitscherlich model. Mitscherlich model parameters were chosen for this analysis because parameter convergence occurred more frequently, which resulted in more site years with sensible DOY max, $p_{\text {estimates }}$ (see Table 4). Arctic, Subtropical, and Tropical climate classes are poorly represented in the Free/Fair-Use dataset (Tables 1, 2; Fig. 1), but Boreal, Temperate, and Temperate Continental classes all contain at least 82 site years of data with which to interpret variability by vegetation type. To explore differences among vegetation types within Boreal,

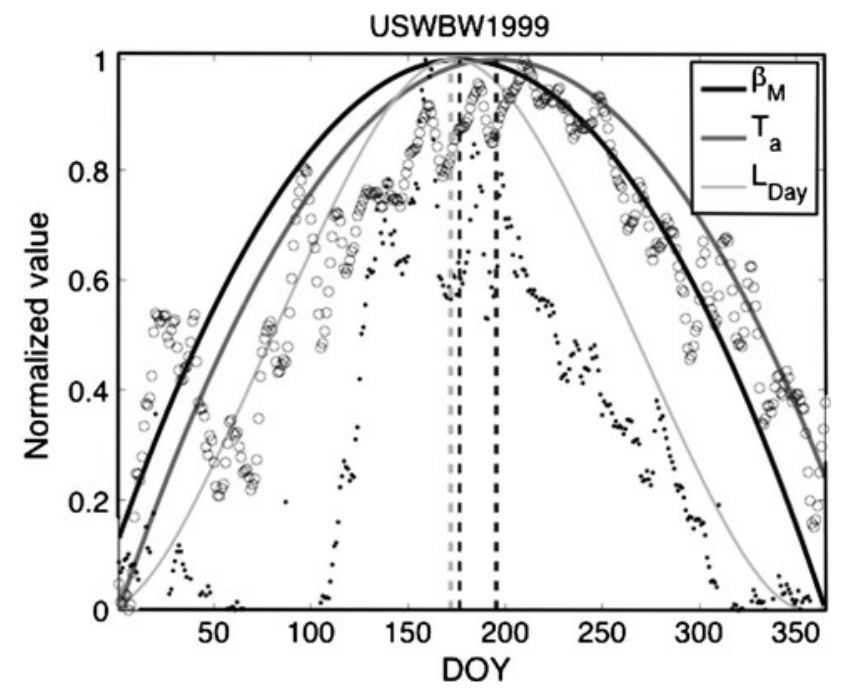

Fig. 3 The seasonal pattern of maximum eddy covariance-measured net ecosystem exchange (NEE) calculated by the Mitscherlich model $\left(\beta_{M}\right.$, black dots $)$ and the seasonal pattern of air temperature $\left(T_{a}\right.$, gray circles) for the Walker Branch Watershed study site (US-WBW, Table 1) in 1999 with second-order polynomials as solid lines and corresponding vertical dashed lines at the vertical axes of symmetry. The data series and parabolas have been all scaled between 0 and 1 in the vertical direction to simplify the visual display. Normalized day length $\left(L_{\text {Day }}\right)$ is shown in the light gray line and the summer solstice [day of year (DOY) 172] is indicated by the light gray vertical dashed line 
Table 4 The mean and standard deviation of the day of year (DOY) at which air temperature $\left(T_{a}\right)$ and light response curve parameters (collectively abbreviated " $p$ ") reach their maximum value $\left(D O Y_{\max }\right)$ for 385 site years of eddy covariance-measured net ecosystem exchange (NEE)

\begin{tabular}{lcrll}
\hline & DOY $_{\max }$ & $\begin{array}{l}N \text { DOY }_{\text {max }, p} \\
<\text { DOY }_{\max , \mathrm{T}_{\mathrm{a}}}\end{array}$ & $\begin{array}{l}N \mathrm{DOY}_{\max , p} \\
>\mathrm{DOY}_{\max , \mathrm{T}_{\mathrm{a}}}\end{array}$ & $\begin{array}{l}N \text { for which } \\
\mathrm{DOY}_{\max , p} \\
\text { exceeded } \\
\text { logical } \\
\text { bounds }\end{array}$ \\
\hline $\mathrm{T}_{\mathrm{a}}$ & $194 \pm 29$ & - & - & - \\
$\alpha_{M}$ & $207 \pm 47$ & 105 & 230 & 13 \\
$\beta_{M}$ & $201 \pm 39$ & 129 & 218 & 19 \\
$\beta_{M}+\gamma_{M}$ & $204 \pm 32$ & 113 & 231 & 20 \\
$\alpha_{N}$ & $214 \pm 48$ & 71 & 209 & 72 \\
$\beta_{N}$ & $201 \pm 26$ & 106 & 192 & 71 \\
$\beta_{N}+\gamma_{N}$ & $202 \pm 25$ & 102 & 196 & 73 \\
\hline
\end{tabular}

$N$ number of site years of occurrence

Temperate, and Temperate Continental climate zones, we performed a one-way ANOVA on DOY max,$p$ using vegetation class as the independent variable. If a main effect was significant, pairwise comparisons within vegetation types and climate classes were analyzed using Tukey's Honestly Significant Difference (HSD) post hoc test. All statistical analyses were performed using $\mathrm{R}$ ( $\mathrm{R}$ Development Core Team 2011) or MATLAB.

\section{Information criteria analyses}

We fit a suite of linear models to every site year of data to examine if incorporating $L_{\text {Day }}$ improves simple models of ecosystem-level photosynthetic parameter seasonality. Model 1 (M1) includes only $T_{\mathrm{a}}$ (i.e., daily values of the photosynthetic parameters are modeled as a function of a fitted slope, the independent variable in this case $T_{\mathrm{a}}$, and a fitted intercept parameter), M2 includes only $L_{\text {Day }}, \mathrm{M} 3$ is a function of $T_{\mathrm{a}}$ plus $\mathrm{L}_{\text {Day }}$, and M4 is equal to M3 plus an interaction term between $T_{\mathrm{a}}$ and $L_{\text {Day }}$. We fit every model to every site year of available data and selected the model with the minimum Akaike's Information Criterion (AIC) value (Akaike 1974). Briefly, AIC measures the relative amount of information lost (via information entropy) for a given model, and, therefore, the model with the minimum AIC value is preferred when discriminating amongst models. AIC penalizes against the number of parameters $n$ and favors models with greater likelihood via:

$\mathrm{AIC}=2 n-2 \ln (L)$

where $L$ is the maximum value of the likelihood function of the model in question calculated using the output of the $\mathrm{lm}$ command in R.
Granger causality

We performed a Granger causality analysis, a method based on the understanding that causes precede effects (Granger 1969), on daily GEP from the Free Fair-Use FLUXNET database (Table 1). Briefly, Granger causality employs a series of $t$ tests and $F$ tests on lagged time series to quantify if there is information in time series $\mathrm{X}$ that contributes to the variability of an independent time series $\mathrm{Y} . T_{\mathrm{a}}$ and $L_{\text {Day }}$ were investigated as causal variables for GEP and GEP normalized by PPFD $\left(\mathrm{GEP}_{n}\right)$. GEP ${ }_{n}$ was chosen for analysis to account for the expectation that longer days that likely have greater PPFD will also likely have greater GEP.

Daily data with a quality control value below 0.90 for GEP (indicating a $90 \%$ acceptance rate of half-hourly flux measurements) and 0.95 for $T_{\mathrm{a}}$ were omitted from the Granger causality calculation, as were site years that contained less than $2 / 3$ of potential data. FLUXNET quality control criteria are described in Reichstein et al. (2005) and Papale et al. (2006). Granger causality was determined to be significant if the Granger F-statistic exceeded the critical value from the F-distribution at the $95 \%$ level. Site years were considered statistically independent such that inference during years in which $L_{\text {Day }}$ or $T_{\mathrm{a}}$ did not Grangercause GEP or GEP ${ }_{n}$ were not confounded by years during which $L_{\text {Day }}$ or $T_{\mathrm{a}}$ Granger-caused GEP (i.e., we selected a more conservative implementation of Granger causality). The maximum lag time considered in the Granger causality calculation was varied between one and 10 weeks to calculate the uncertainty of the fraction of site years in which a Granger causal relationship was observed.

\section{Results}

Seasonality of photosynthetic parameters

The $95 \%$ confidence intervals about $\mathrm{DOY}_{\max , \mathrm{T}_{\mathrm{a}}}$ exceeded 1 day in only five instances out of 385 site years, and the $95 \%$ confidence interval about DOY $_{\max , p}$ did not exceed 1 day across all site years and parameters examined. Subsequently, we focus our statistical analysis on patterns among site years rather than uncertainty within site years. DOY $_{\max , p}$ occasionally fell outside of the logical range of 0-365 (or 366), often due to incomplete measurements across the site year. These site years were excluded from further analyses.

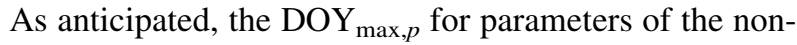
rectangular hyperbola could not be calculated for many (>70) site years due to difficulties in fitting the non-rectangular hyperbola to noisy eddy covariance data (Table 4). We focus on parameters of the Mitscherlich model in subsequent analyses to avoid excluding site years for this 
reason. The mean DOY ${\max , T_{a}}_{a}$ across all site years occurred on average before the mean $\mathrm{DOY}_{\text {max }, p}$ for all parameter combinations examined here (two-tailed $t$ test, $P<0.05$; Table 4). Maximum values of $\beta_{M}$ and $\beta_{M}+\gamma_{M}$ occurred on average 7-10 days after DOY ${ }_{\max , \mathrm{T}_{a}}$, and maximum values of $\alpha_{M}$ occurred on average 2 weeks after DOY ${\text { max, } T_{a}}_{a}$. Despite statistically significant differences in mean DOY $_{\max , T_{a}}$ and DOY ${ }_{\max , p}$ across all site years, $\mathrm{DOY}_{\max , p}$ occurred earlier than DOY $\mathrm{max}_{\mathrm{a}}$ in $31-37 \%$ of all instances, depending on the parameter chosen (Table 4).

Analysis of variance of parameter seasonality by climate and vegetation type

DOY $_{\text {max }, p}$ values below 150 and above 250 were identified as outliers in an interquartile analysis, and excluding these values resulted in a normal distribution of values for each parameter as identified by Komolgorov-Smirnov tests. Thus, we focus our statistical analysis of seasonal parameter variability by climate and vegetation type on site years with $\mathrm{DOY}_{\text {max }, p}$ between 150 and 250. DOY $\mathrm{Dax}, p_{\text {, }}$ for the alpha parameter of the Mitscherlich model $\left(\alpha_{M}\right)$ was significantly different by vegetation type $\left(F_{5,278}=3.1\right.$; $P<0.01)$, but correcting for multiple comparisons using Tukey's HSD resulted in no pairwise comparisons that were significantly different. DOY $\mathrm{Dax}, p_{\text {for }}$ foth $\beta_{M}$ and $\beta_{M}+\gamma_{M}$ did not differ by vegetation type, but were significantly different by climate type $\left(\beta_{M}: F_{5,311}=8.1\right.$; $\left.P<0.0001, \quad \beta_{M}+\gamma_{M}: \quad F_{5,319}=13.6 ; \quad P<0.0001\right)$. Namely, DOY $\beta_{\max , p}$ for $\beta_{M}$ in the Temperate climate zone occurred nearly 11 days earlier than in the Boreal zone $(P<0.00001)$ and over 1 week earlier than in the Temperate Continental zone $\left(P<0.005\right.$; Fig. 4). DOY max,$p_{\text {for }}$ $\beta_{M}$ in the Tropical climate zone occurred nearly 1 month earlier than in the Boreal zone and nearly 3 weeks earlier than in the Temperate Continental zone $(P<0.00001$ in both cases). DOY max,$p_{\text {for }} \beta_{M}+\gamma_{M}$ was lower in the Tropical zone than in all other climate zones investigated by an average of 39 days $(P<0.05$ in all cases). DOY max,$p$ for $\beta_{M}+\gamma_{M}$ occurred ca. 2 weeks earlier in the Subtropical and Temperate zones than the Boreal climate zone $(P<0.01)$. DOY max,$p_{\text {for }} \beta_{M}+\gamma_{M}$ occurred ca. 1 week earlier in the Temperate zone than the Temperate Continental zone $(P<0.0005)$. DOY $\max , p$ for $\beta_{M}+\gamma_{M}$ also occurred 10 days earlier in wetland vegetation than in evergreen needleleaf forests in the Boreal zone $(P<0.05)$.

Minimal models for explaining the seasonal variability of photosynthetic parameters

We were unable to calculate AIC values for only five of the 385 site years due to insufficient data. Results of the AIC

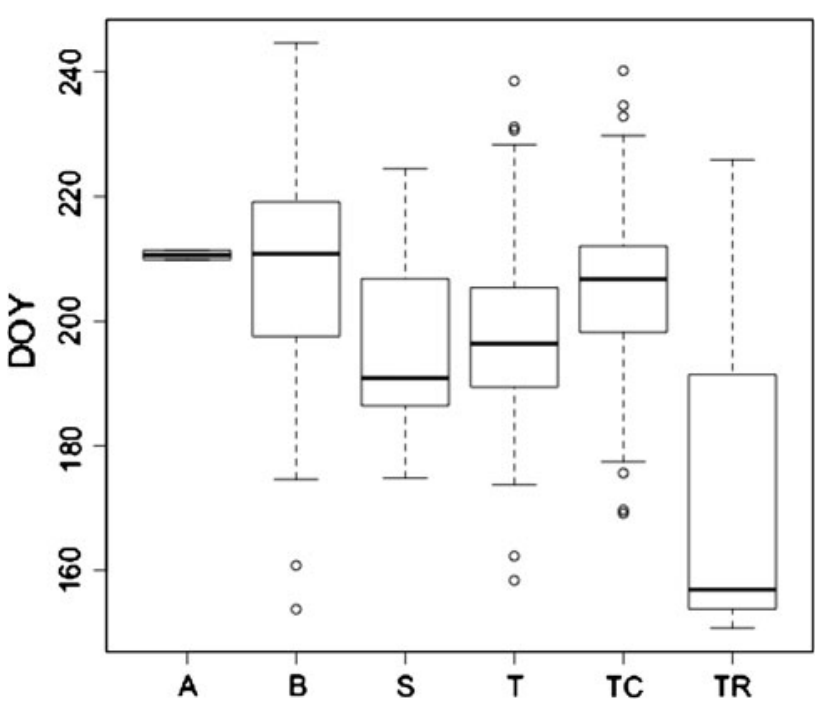

Fig. 4 A box-and-whisker plot for the day of year (DOY) of maximum seasonal parameter values for the maximum ecosystem $\mathrm{CO}_{2}$ uptake $\left(\beta_{M}\right)$ parameter for the Mitscherlich model grouped by climate class. Climate group following the Köppen-Geiger classification scheme. $A$ arctic, $B$ boreal, $S$ subtropical, $T$ temperate, TC temperate continental, $T R$ tropical

analysis for the $\alpha_{M}, \beta_{M}$, and $\beta_{M}+\gamma_{M}$ parameters were similar (Table 5), and we discuss only $\beta_{M}$ parameter results for simplicity. For $\beta_{M}$, M1 had the lowest AIC value for 32 (of 380) site years, M2 had the lowest AIC value for 17 site years, and M3 and M4 were the lowest for 51 and 280 site years, respectively (Table 5). In other words, the preferred model with the lowest AIC value included $L_{\text {Day }}$ (i.e., M2, M3, and M4) in over $90 \%$ (348/380) of all site years examined here. On the other hand, excluding $T_{\mathrm{a}}$ (i.e., M2) resulted in a preferred model less than $5 \%$ of the time. When considering only M1 and M2 (i.e., univariate linear models of $T_{\mathrm{a}}$ and $L_{\text {Day }}$, respectively), M1 had a lower AIC value than M2 on 236 occasions (62\% of all site years) and the opposite held on 144 occasions. The proportion of sites for which the AIC value of M2 was less than the AIC

Table 5 The number of site years for which linear models $(M)$ of the seasonal variability different Mitscherlich model parameters (Eq. 2) had the lowest value of Akaike's Information Criterion (AIC), including the number of site years for which the AIC value of model M1 (i.e., a model that included only air temperature, $T_{a}$ ) was less than M2 (a model with only day length, $L_{\text {Day }}$ )

\begin{tabular}{llrrc}
\hline Model & Independent variables & $\alpha_{M}$ & $\beta_{M}$ & $\beta_{M}+\gamma_{M}$ \\
\hline M1 & $T_{\mathrm{a}}$ & 32 & 32 & 26 \\
M2 & $L_{\text {Day }}$ & 23 & 17 & 15 \\
M3 & $T_{\mathrm{a}}+L_{\text {Day }}$ & 68 & 51 & 68 \\
M4 & $T_{\mathrm{a}}+L_{\text {Day }}+T_{\mathrm{a}} \times L_{\text {Day }}$ & 258 & 280 & 271 \\
M1 $<$ M2 & - & 272 & 236 & 257 \\
M2 $<$ M1 & - & 113 & 144 & 128 \\
\hline
\end{tabular}


value of M1 (i.e., instances in which a model including only $L_{\text {Day }}$ is preferred over a model including only $T_{\mathrm{a}}$ ) is significantly greater in the Temperate zone than in the Temperate Continental zone ( 0.50 vs $0.26, P<0.0005)$ or in the Boreal zone $(0.50$ vs $0.32, P<0.005)$.

Whereas simple linear models with only $\mathrm{T}_{\mathrm{a}}$ (M1) explained nearly $30 \%$ of the variability of $\beta_{M}$ on average and a model with only $L_{\text {Day }}(\mathrm{M} 2)$ explained $23 \%$ of the variability of $\beta_{M}$, the model that included both $\mathrm{T}_{\mathrm{a}}, \mathrm{L}_{\text {Day }}$, and an interaction term between the two (M4) explained an average of $40 \%$, and up to $95 \%$, of the variability of $\beta_{M}$. The simple linear models explored here explained more of the variability of $\beta_{M}+\gamma_{M}$ than $\beta_{M}$ or $\alpha_{M}$ (which was similar to $\beta_{M}$ ); M1 and M2 explained over $40 \%$ and nearly $30 \%$ of the variability of $\beta_{M}+\gamma_{M}$, respectively. The model that included $T_{\mathrm{a}}, L_{\text {Day }}$, and an interaction term between the two (M4) explained $53 \%$ of the variability of $\beta_{M}+\gamma_{M}$, on average.

\section{Granger causality}

$L_{\text {Day }}$ always Granger-caused $T_{\mathrm{a}}$, as anticipated (Table 6). $L_{\text {Day }}$ Granger-caused GEP $\left(\mathrm{GEP}_{n}\right)$ in $99 \%(92 \%)$ of the site years, and while temperature Granger-caused GEP in a mere $32 \%$ of site years, it Granger-caused $\mathrm{GEP}_{n}$ in $81 \%$ of site years (Table 6). The proportion of site years in which $T_{\mathrm{a}}$ Granger-caused GEP and $\mathrm{GEP}_{n}$ are significantly less than the percent of cases in which $L_{\text {Day }}$ Granger-caused GEP and $\operatorname{GEP}_{n}(P<0.05$, Student's t-test). We analyzed opposite cases for completeness; GEP $\left(\mathrm{GEP}_{n}\right)$ Grangercaused $\mathrm{L}_{\text {Day }}$ in $51 \%(41 \%)$ of all site years, but Grangercaused $\mathrm{T}_{\mathrm{a}}$ in $85 \%(35 \%)$ of all site years (Table 6). $\mathrm{T}_{\mathrm{a}}$ Granger-caused $\mathrm{L}_{\text {Day }}$ in $40 \%$ of site years.

Table 6 The fraction of 385 site years of eddy covariance measurements for which the explanatory variable $(X)$ Granger-caused causal variable $(Y)$, considering all comparisons of day length $\left(L_{D a y}\right.$, as a surrogate for photoperiod), air temperature $\left(T_{a}\right)$, gross ecosystem productivity $(G E P)$, and GEP normalized by photosynthetically active radiation $\left(G E P_{n}\right)$

\begin{tabular}{lll}
\hline $\mathrm{X}$ & $\mathrm{Y}$ & $\begin{array}{l}\text { Fraction of site years for } \\
\text { which X Granger-caused } \mathrm{Y}\end{array}$ \\
\hline$L_{\text {Day }}$ & $\mathrm{GEP}$ & $0.99 \pm 0.000$ \\
$T_{\mathrm{a}}$ & $\mathrm{GEP}$ & $0.32 \pm 0.002$ \\
$L_{\text {Day }}$ & $\mathrm{GEP}_{n}$ & $0.92 \pm 0.006$ \\
$T_{\mathrm{a}}$ & $\mathrm{GEP}_{n}$ & $0.81 \pm 0.007$ \\
$\mathrm{GEP}$ & $L_{\text {Day }}$ & $0.51 \pm 0.05$ \\
$\mathrm{GEP}$ & $T_{\mathrm{a}}$ & $0.85 \pm 0.006$ \\
$\mathrm{GEP}_{\mathrm{n}}$ & $L_{\text {Day }}$ & $0.41 \pm 0.05$ \\
$\mathrm{GEP}_{\mathrm{n}}$ & $T_{\mathrm{a}}$ & $0.35 \pm 0.01$ \\
$L_{\text {Day }}$ & $T_{\mathrm{a}}$ & $1.00 \pm 0$ \\
$T_{\mathrm{a}}$ & $L_{\text {Day }}$ & $0.40 \pm 0.03$ \\
\hline
\end{tabular}

\section{Discussion}

Photoperiod and temperature controls on canopy photosynthetic function

Our results confirm that $L_{\text {Day }}$ improves our understanding of the seasonal variability of maximum $\mathrm{CO}_{2}$ uptake, as also demonstrated by studies at the leaf scale (Bauerle et al. 2012) and ecosystem scale (Thum et al. 2007) using Farquhar et al. (1980) model parameters. Results also demonstrate that $\mathrm{L}_{\text {Day }}$ should not be excluded from minimal models of parameter variability in most cases (Table 5), offering support for our experimental hypothesis. However, $T_{\mathrm{a}}$ tends to be a better descriptor of the seasonal variability of canopy-scale photosynthetic parameters than $L_{\text {Day }}$; for example, peak seasonal values of $\alpha_{M}, \beta_{M}$, and $\beta_{M}+\gamma_{M}$ usually occur after the seasonal peak of $T_{\mathrm{a}}$ (Table 4) and models with only $T_{\mathrm{a}}$ have lower AIC values more often than models with only $L_{\text {Day }}$ (Table 5). The best results occurred when $T_{\mathrm{a}}$ and $L_{\text {Day }}$ were used in concert; M4 explained over $50 \%$ of the variability of $\beta_{M}+\gamma_{M}$, on average, before even considering hydrologic stress (Yuan et al. 2007), leaf area index (Groenendijk et al. 2011), or other variables that are critical for explaining canopy photosynthesis. In other words, results demonstrate that most of the variability in maximum ecosystem-scale carbon uptake can be explained using $T_{\mathrm{a}}$ and $L_{\text {Day }}$ in combination without any other variables in the sites explored here.

The Granger causality analysis also demonstrates that $\mathrm{L}_{\text {Day }}$ helps to explain the seasonal variability in GEP; $L_{\text {Day }}$ Granger-caused GEP in almost all instances, even after normalizing by PPFD (i.e., $\mathrm{GEP}_{n}$ ) to account for its role in driving GEP. $T_{\mathrm{a}}$ Granger-caused $\mathrm{GEP}_{n}$ in most instances as well, but not as frequently as $L_{\text {Day }}$ (Table 6). Both the AIC and Granger causality analyses substantiate that $L_{\text {Day }}$ contributes to the seasonality of $\mathrm{GEP}_{n}$ and the parameters that determine the relationship between GEP and PPFD, suggesting that the inclusion of $L_{\text {Day }}$ in photosynthesis models at the ecosystem scale is likely to result in model improvement, particularly in Temperate, Temperate Continental, and Boreal climate zones.

The role of ecosystem and climate type

Tropical, Subtropical, and Arctic climate zones had fewer available site years for analysis, and we caution against extrapolating our results beyond the Temperate, Temperate Continental, and Boreal climate zones for which more data were available. Results of the AIC analysis demonstrate that univariate linear models with only $\mathrm{L}_{\text {Day }}$ are preferred more often in the Temperate zone than the Temperate Continental or Boreal zone, where temperature variability and constraints on photosynthesis are likely to be more pronounced. 
$\alpha_{M}$ differed by vegetation type rather than climate type, but without distinct differences among specific vegetation types and we note that it is often treated as a near constant (albeit dependent on temperature, Ehleringer and Björkman 1977) in leaf-level studies (Lambers et al. 2000). Maximum seasonal values of $\beta_{M}$ and $\beta_{M}+\gamma_{M}$ (i.e., DOY ${ }_{\max , p}$ ) often peaked earlier in warmer regions like subtropical and tropical climate zones as might be expected. Interestingly, vegetation type itself rarely explained differences in DOY $_{\text {max }, p}$, for $\beta_{M}$ and $\beta_{M}+\gamma_{M}$, except for wetland ecosystems and evergreen needleleaf forests in the Boreal zone. These results highlight the important role of climate on controlling the seasonal variability of photosynthetic physiology, and point to the emerging finding that plant functional type schemes may not be the best way to partition vegetation functioning in global models (Pavlick et al. 2012; Harrison et al. 2010) because they may not effectively capture the variability of vegetation functioning within and among vegetation classes (e.g., Kattge et al. 2011).

Results from different light response parameters

Both $\beta_{M}$ and $\beta_{M}+\gamma_{M}$ are related to $J_{\max }$ insomuch as they are related to the maximum electron transport rate at high irradiance. $J_{\max }$ is known to be a function of temperature, as is $\alpha_{M}$ (Ehleringer and Björkman 1977). However, M2 (the model with only $L_{\text {Day }}$ ) was a better descriptor of $\beta_{M}$ and $\beta_{M}+\gamma_{M}$ more often than $\alpha_{M}$ (Table 5), likely because $\alpha_{M}$ tends to be less-seasonal (Groenendijk et al. 2011). Results also point to important differences between leaf-scale and canopy-scale results; Bauerle et al. (2012) noted a decline in $J_{\text {max }}$ and $V_{c, \text { max }}$ in late June at the leaf scale across tree species with average seasonal peaks around DOY 167-170 near the summer solstice on DOY 172 (during most years). Our estimated peaks in $\alpha_{M}, \beta_{M}$, and $\beta_{M}+\gamma_{M}$ occurred on average over 1 month later, for reasons that remain unclear. We note that our ecosystem-scale results inherently include photosynthetic contributions from shaded leaves and understory species, when present, and fewer studies on photosynthetic seasonality have been conducted on shaded and understory leaves (Herrick and Thomas 2003). Care was taken to avoid choosing models and approaches that drift extensively above observed flux values when modeling light response (Fig. 3). We chose multiple models to foster a conservative interpretation of results, although we note that fitting light response curves under conditions that are not light limiting remains an ongoing challenge (Lasslop et al. 2010; Reichstein et al. 2012).

The "errors in $\mathrm{x}$ " problem and modeling implications

Our objective was to explore hundreds of site years of eddy covariance data to uncover the role of $L_{\text {Day }}$ and $T_{\mathrm{a}}$ in determining seasonal patterns of ecosystem-scale photosynthetic light response and GEP. We anticipate that incorporating $L_{\text {Day }}$ into ecosystem-scale models will improve their ability to simulate seasonal patterns in GEP, but the steps that one might take to incorporate this information depends on the type of model at hand. For example, Schwalm et al. (2010) characterized GPP models for the North American Carbon Program synthesis effort as following either enzyme kinetic, stomatal conductance, or light-use efficiency-based formulations, and noted that more complicated model formulations need not lead to improvement in performance. Light-use efficiency-based models are arguably the simplest to modify, for example by adding a multiplier based on $L_{\text {Day }}$. Adjusting parameters of enzyme kinetic-based models, for example $J_{\max }$, may also improve model simulation estimates of the seasonal variability of photosynthetic function (Bauerle et al. 2012) as demonstrated for the CLM (Bonan et al. 2011). Whether these suggested improvements to photosynthetic subroutines represent an improvement across different ecosystem models for different biome types remains to be seen, but large intercomparison efforts have demonstrated pronounced model-data misfit (Schaefer et al. 2012; Schwalm et al. 2010) at diurnal to interannual time scales (Dietze et al. 2011), including models that used model-data fusion schemes (Ricciuto et al. 2008). These observations suggest that models still require mechanistic improvements to capture the variability and magnitude of observed canopyscale $\mathrm{CO}_{2}$ uptake (Williams et al. 2009).

Our data-driven analysis does not suggest that simply adding $L_{\text {Day }}$ to models of canopy photosynthesis should take the place of mechanistic modifications to models of ecosystem-scale $\mathrm{CO}_{2}$ uptake (Ryu et al. 2011; Groenendijk et al. 2011; Krinner et al. 2005; Sitch et al. 2003; Baldocchi et al. 2002). Rather, adding $L_{\text {Day }}$ as an independent variable may help to explain the variability of light response curve parameters and thereby photosynthetic physiology. An ongoing challenge with ecosystem-scale photosynthesis models centers around uncertainties in model input variables like leaf area index, canopy $N$, water status, and sunlit/shaded leaf fraction. Since $L_{\text {Day }}$ can be computed with accuracy at any point on the globe, and changes on timescales that are longer than those explored by most land surface models [i.e., thousands of years (Hays et al. 1976), incorporating $L_{\text {Day }}$ as an independent model variable will likely improve models of canopy photosynthesis. It is important to note that including $L_{\text {Day }}$ can only aid a model of photosynthesis at the time scales that $L_{\text {Day }}$ varies, in this case over the course of seasons. $T_{\mathrm{a}}$, on the other hand, varies across turbulent to geologic time scales, and incorporating this rich, multi-scale behavior into photosynthesis models can improve their frequency response. We caution against extrapolating our results, dominated by temperate and boreal ecosystems, to 
portions of the globe where seasonal $\mathrm{L}_{\text {Day }}$ fluctuations are small; the percent of variability in $\beta_{M}$ and $\beta_{M}+\gamma_{M}$ explained by M4 rarely exceeded $40 \%$ in sites at latitudes below the 29th parallel. The amount of variability in $\beta_{M}$ or $\beta_{M}+\gamma_{M}$ explained by $L_{\text {Day }}$ alone (i.e., M2) at latitudes less than $29^{\circ}$ tended to be less than $10 \%$ (but up to $40 \%$ ). In fact, there was a significant relationship between latitude and the amount of variability explained by M1, M3, and M4 for $\alpha_{M}$ and $\beta_{M}+\gamma_{M}(P<0.05)$; results improve as one moves away from the tropics and into ecosystems dominated by seasonality in temperature. We also note that variability in temperature tends to dominate the seasonality of photosynthesis in these ecosystems, which furthermore do not experience substantial anthropogenic management to the degree of managed crops. We note that incorporating photoperiodic control into the CLM improved Carbon Land Model Intercomparison Project (C-LAMP) metrics (Randerson et al. 2009), mostly in mid-to-high latitude flux stations (Bauerle et al. 2012), further highlighting important geographic distinctions in our findings. Ideal approaches for incorporating $L_{\text {Day }}$ into models of canopy photosynthesis remains an important topic for future research. Detailed studies at well-characterized flux sites that include seasonal observations of leaf area index and distribution, canopy $N$, canopy light penetration, and water status are needed to ascertain the degree of improvement that $L_{\text {Day }}$ may add in models of canopy photosynthesis.

Acknowledgments This work used eddy covariance data acquired by the FLUXNET community and in particular by the following networks: AmeriFlux (U.S. Department of Energy, Biological and Environmental Research, Terrestrial Carbon Program (DE-FG0204ER63917 and DE-FG02-04ER63911)), AfriFlux, AsiaFlux, CarboAfrica, CarboEuropeIP, CarboItaly, CarboMont, ChinaFlux, Fluxnet-Canada (supported by CFCAS, NSERC, BIOCAP, Environment Canada, and NRCan), GreenGrass, KoFlux, LBA, NECC, OzFlux, TCOS-Siberia, USCCC. We acknowledge the financial support to the eddy covariance data harmonization provided by CarboEuropeIP, FAOGTOS-TCO, iLEAPS Max Planck Institute for Biogeochemistry, National Science Foundation, University of Tuscia, Université Laval and Environment Canada and US Department of Energy and the database development and technical support from Berkeley Water Center, Lawrence Berkeley National Max Planck Institute for Biogeochemistry, National Science Foundation, University of Tuscia, Université Laval and Environment Canada and US Department of Energy and the database development and technical support from Berkeley Water Center, Lawrence Berkeley National Laboratory, Microsoft Research eScience, Oak Ridge National Laboratory, University of California - Berkeley, University of Virginia. The authors thank Ram Oren of Duke University for the encouragement to pursue the present research and Michael Kleder of Delta Epsilon Technologies, LLC for providing the MATLAB code for the world map with political boundaries. PCS acknowledges funding from the National Science Foundation ('Scaling ecosystem function: Novel Approaches from MaxEnt and Multiresolution', Division of Biological Infrastructure \#1021095) and the State of Montana. WLB was supported in part by USDA Grant 2009-51181-05768, Cooperative Agreement 58-6618-2-0209 and the State of Colorado.

\section{References}

Akaike H (1974) A new look at the statistical model identification. IEEE Trans Autom Control 19:716-723

Amiro BD, Orchansky AL, Barr AG, Black TA, Chambers SD, Chapin FS III, Goulden ML, Litvak M, Liu HP, McCaughey JH, McMillan A, Randerson JT (2006) The effect of post-fire stand age on the boreal forest energy balance. Agric For Meteorol 140(1-4):41-50

Anthoni PM, Knohl A, Rebmann C, Freibauer A, Mund M, Ziegler W, Kolle O, Schulze ED (2004) Forest and agricultural land-usedependent $\mathrm{CO}_{2}$ exchange in Thuringia, Germany. Glob Change Biol 10(12):2005-2019. doi:10.1111/j.1365-2486.2004.00863.x

Aradóttir ÁL, Thorgeirsson H, McCaughey JH, Strachan IB, Robertson A (1997) Establishment of a black cottonwood plantation on an exposed site in Iceland: plant growth and site energy balance. Agric For Meteorol 84(1-2):1-9

Asner GP (1998) Biophysical and biochemical sources of variability in canopy reflectance. Remote Sens Environ 64:234-253

Aubinet M, Grelle A, Ibrom A, Rannik Ü, Moncrieff J, Foken T, Kowalski AS, Martin PH, Berbigier P, Bernhofer C, Clement R, Elbers J, Granier A, Grunwald T, Morgenstern K, Pilegaard K, Rebmann C, Snijders W, Valentini R, Vesala T (2000) Estimates of the annual net carbon and water exchange of forests: the EUROFLUX methodology. Adv Ecol Res 30:113-175

Aubinet M, Chermanne B, Vandenhaute M, Longdoz B, Yernaux M, Laitat $\mathrm{E}$ (2001) Long term carbon dioxide exchange above a mixed forest in the Belgian Ardennes. Agric For Meteorol 108(4):293-315

Aurela M, Laurila T, Tuovinen JP (2002) Annual $\mathrm{CO}_{2}$ balance of a subarctic fen in northern Europe: importance of the wintertime efflux. J Geophys Res-Atmos 107 (D21):4607. doi:10.1029/2002 JD002055

Baldocchi DD (2008) 'Breathing' of the terrestrial biosphere: lessons learned from a global network of carbon dioxide flux measurements systems. Aust J Bot 56:1-26

Baldocchi D, Falge E, Gu LH, Olson R, Hollinger D, Running S, Anthoni P, Bernhofer C, Davis K, Evans R, Fuentes J, Goldstein A, Katul G, Law B, Lee XH, Malhi Y, Meyers T, Munger W, Oechel W, Paw UKT, Pilegaard K, Schmid HP, Valentini R, Verma S, Vesala T, Wilson K, Wofsy S (2001) FLUXNET: a new tool to study the temporal and spatial variability of ecosystem-scale carbon dioxide, water vapor, and energy flux densities. Bull Am Meteorol Soc 82(11):2415-2434

Baldocchi DD, Wilson KB, Gu L (2002) How the environment, canopy structure and canopy physiological functioning influence carbon, water and energy fluxes of a temperate broad-leaved deciduous forest - an assessment with the biophysical model CANOAK. Tree Physiol 22:1065-1077

Bauerle WL, Oren R, Way DA, Qian SS, Stoy PC, Thornton PE, Bowden JD, Hoffman FM, Reynolds RF (2012) Photoperiodic regulation of the seasonal pattern of photosynthetic capacity and the implications for carbon cycling. Proc Natl Acad Sci 109(22):8612-8617. doi:10.1073/pnas.1119131109

Berbigier P, Bonnefond J-M, Mellmann P (2001) $\mathrm{CO}_{2}$ and water vapour fluxes for 2 years above Euroflux forest site. Agric For Meteorol 108(3):183-197

Berger BW, Davis KJ, Yi C, Bakwin PS, Zhao CL (2001) Long-term carbon dioxide fluxes from a very tall tower in a northern forest: flux measurement methodology. J Atmos Ocean Technol 18:529-542

Bergeron O, Margolis HA, Black TA, Coursolle C, Dunn AL, Barr AG, Wofsy SC (2007) Comparison of carbon dioxide fluxes over three boreal black spruce forests in Canada. Glob Change Biol 13(1):89-107. doi:10.1111/j.1365-2486.2006.01281.x 
Beringer J, Hutley L, Kilinc M, McGuire AD, McHugh I (2006) Water, energy and carbon fluxes from the world's tallest anigosperm (Eucalyptus regnans) at Wallaby Creek, southeastern Australia. In: International Geographical Union Conference "Regional Responses to Global Changes: a view from the Antipodes", Brisbane, 2006

Bernhofer C, Aubinet M, Clement R, Grelle A, Grunwald T, Ibrom A, Jarvis P, Rebmann C, Schulze E-D, Tenhunen J (2003) Spruce forests (Norway and Sitka Spruce, including Douglas Fir): carbon and water fluxes and balances, ecological and ecophysiological determinants. In: Valentini R (ed) Fluxes of carbon, water and energy of european forests. Springer, Berlin

Bonan GB, Lawrence PJ, Oleson KW, Levis S, Jung M, Reichstein M, Lawrence DM, Swenson SC (2011) Improving canopy processes in the Community Land Model version 4 (CLM4) using global flux fields empirically inferred from FLUXNET data. J Geophys Res 116 (G2):G02014. doi:10.1029/2010jg00 1593

Campbell GS, Norman JM (1998) An introduction to environmental biophysics, 2nd edn. Springer, New York

Cescatti A, Marcolla B (2004) Drag coefficient and turbulence intensity in conifer canopies. Agric For Meteorol 121(3-4):197206

Chen J, Falk M, Euskirchen E, Paw UKT, Suchanek TH, Ustin SL, Bond BJ, Brosofske KD, Phillips N, Bi R (2002) Biophysical controls of carbon flows in three successional Douglas-fir stands based on eddy-covariance measurements. Tree Physiol 22(2-3): 169-177. doi:10.1093/treephys/22.2-3.169

Chesher A (1991) The effect of measurement error. Biometrika 78(3):451-462. doi:10.1093/biomet/78.3.451

Chojnicki BH, Urbaniak M, Jozefczyk D, Augustin J, Olejnik J (2007) Measurements of gas and heat fluxes at Rzecin wetland. In: Okruszko T, Maltby E, Szatylowicz J, Miroslow-Swiakek D, Kotowski W (eds) Wetlands: monitoring. modelling and management. Taylor \& Francis, London, pp 125-131

Clark KL, Gholz HL, Moncrieff JB, Cropley F, Loescher HW (1999) Environmental controls over net exchanges of carbon dioxide from contrasting Florida ecosystems. Ecol Appl 9(3):936-948

Cook BD, Davis KJ, Wang W, Desai AR, Berger BW, Teclaw RM, Martin JM, Bolstad PV, Bakwin P, Yi C, Heilman W (2004) Carbon exchange and venting anomalies in an upland deciduous forest in northern Wisconsin, USA. Agric For Meteorol 126: 271-295

Curtis PS, Hanson PJ, Bolstad P, Barford C, Randolph JC, Schmid HP, Wilson KB (2002) Biometric and eddy-covariance based estimates of annual carbon storage in five eastern North American deciduous forests. Agric For Meteorol 113:3-19

Darwin F (1898) Observations on stomata. Philos Transact R Soc B 190:531-621

de Dios VR, Goulden ML, Ogle K, Richardson AD, Hollinger DY, Davidson EA, Alday JG, Barron-Gafford GA, Carrara A, Kowalski AS, Oechel WC, Reverter BR, Scott RL, Varner RK, Díaz-Sierra R, Moreno JM (2012) Endogenous circadian regulation of carbon dioxide exchange in terrestrial ecosystems. Glob Change Biol 18(6):1956-1970. doi:10.1111/j.1365-2486. 2012.02664.x

de Pury DGG, Ceulemans R (1997) Scaling-up carbon fluxes from leaves to stands in a patchy coniferous/deciduous forest. In: Mohren GMJ (ed) Impacts of global change on tree physiology and forest ecosystems. Kluwer Academic, Dordrecht, pp 263-272

DeForest J, Noormets A, McNulty S, Sun G, Tenney G, Chen J (2006) Phenophases alter the soil respiration-temperature relationship in an oak-dominated forest. Int J Biometeorol 51(2):135-144. doi:10.1007/s00484-006-0046-7
Desai AR (2010) Climatic and phenological controls on coherent regional interannual variability of carbon dioxide flux in a heterogeneous landscape. J Geophys Res 115:G00J02. doi: 10.1029/2010jg001423

Desai AR, Bolstad PV, Cook BD, Davis KJ, Carey EV (2005) Comparing net ecosystem exchange of carbon dioxide between an old-growth and mature forest in the upper Midwest, USA. Agric For Meteorol 128:33-55

Desai AR, Noormets A, Bolstad PV, Chen J, Cook BD, Davis KJ, Euskirchen ES, Gough C, Martin JG, Ricciuto DM, Schmid HP, Tang J, Wang W (2008a) Influence of vegetation and seasonal forcing on carbon dioxide fluxes across the Upper Midwest, USA: implications for regional scaling. Agric For Meteorol 148(2):288-308

Desai AR, Richardson AD, Moffat AM, Kattge J, Hollinger DY, Barr AG, Falge E, Noormets A, Papale D, Reichstein M, Stauch VJ (2008b) Cross-site evaluation of eddy covariance GPP and RE decomposition techniques. Agric For Meteorol 148:821-838

Detto M, Molini A, Katul GG, Stoy PC, Palmroth S, Baldocchi DD (2012) Assessing cause and effect in ecological time series: an application of conditional Granger's spectral causality theory. Am Nat 179:524-535

Dietze M, Vargas R, Richardson AD, Stoy PC, Barr AG, Anderson RS, Arain A, Baker IT, Black TA, Chen JM, Ciais P, Flanagan LB, Gough CM, Grant RF, Hollinger DY, Izaurralde C, Kucharik CJ, Lafleur PM, Liu S, Lokupitiya E, Luo Y, Munger JW, Peng C, Poulter B, Price DT, Ricciuto DM, Riley WJ, Sahoo AK, Schaefer K, Tian H, Verbeeck H, Verma SB (2011) Characterizing the performance of ecosystem models across time scales: a spectral analysis of the North American Carbon Program site-level synthesis. J Geophys Res 116:G04029. doi: 10.1029/2011JG001661

Dolman AJ, Moors EJ, Elbers JA (2002) The carbon uptake of a mid latitude pine forest growing on sandy soil. Agric For Meteorol 111(3):157-170

Dušek J, Čížková H, Czerný R, Taufarová K, Šmídová M, Janouš D (2009) Influence of summer flood on the net ecosystem exchange of $\mathrm{CO}_{2}$ in a temperate sedge-grass marsh. Agric For Meteorol 149(9):1524-1530

Ehleringer J, Björkman O (1977) Quantum yields for $\mathrm{CO}_{2}$ uptake in $\mathrm{C}_{3}$ and $\mathrm{C}_{4}$ plants. Plant Physiol 59(1):86-90. doi:10.1104/ pp. 59.1 .86

Fang C, Moncrieff JB, Gholz HL, Clark KL (1998) Soil $\mathrm{CO}_{2}$ efflux and its spatial variation in a Florida slash pine plantation. Plant Soil 205(2):135-146. doi:10.1023/a:1004304309827

Farquhar GD, von Caemmerer S, Berry JA (1980) A biochemical model of photosynthetic $\mathrm{CO}_{2}$ assimilation in leaves of $\mathrm{C}_{3}$ species. Planta 149:78-90

Finnigan JJ, Leuning R (2000) Long term flux measurementscoordinate systems and averaging. In: Proceedings of the International Workshop for Advanced Flux Network and Flux Evaluation, Center for Global Environmental Research, National Institute for Environmental Studies, Hokkaido, 2000. pp 51-56

Fisher JI, Richardson AD, Mustard JF (2007) Phenology model from surface meteorology does not capture satellite-based greenup estimations. Glob Change Biol 13(3):707-721. doi:10.1111/ j.1365-2486.2006.01311.x

Foken T, Aubinet M, Leuning R (2012) The eddy covariance method. In: Aubinet M, Vesala T, Papale D (eds) Eddy covariance: a practical guide to measurement and data analysis. Springer, Dordrecht, p 460

Foody GM, Atkinson PM (2006) Uncertainty in remote sensing and GIS. Wiley, New York. doi:10.1002/0470035269.fmatter

Fuller WA (1987) Measurement error models. Wiley, New York 
Giasson M-A, Coursolle C, Margolis HA (2006) Ecosystem-level $\mathrm{CO}_{2}$ fluxes from a boreal cutover in eastern Canada before and after scarification. Agric For Meteorol 140(1-4):23-40

Gilmanov TG, Verma SB, Sims PL, Meyers TP, Bradford JA, Burba GG, Suyker AE (2003) Gross primary production and light response parameters of four Southern Plains ecosystems estimated using long-term $\mathrm{CO}_{2}$-flux tower measurements. Glob Biogeochem Cycle 17:1071

Gioli B, Miglietta F, De Martino B, Hutjes RWA, Dolman HAJ, Lindroth A, Schumacher M, Sanz MJ, Manca G, Peressotti A, Dumas EJ (2004) Comparison between tower and aircraft-based eddy covariance fluxes in five European regions. Agric For Meteorol 127(1-2):1-16

Goulden ML, Daube BC, Fan S-M, Sutton DJ, Bazzaz A, Munger JW, Wofsy SC (1997) Physiological responses of a black spruce forest to weather. J Geophys Res 102 (D24):28987-28996

Goulden ML, Winston GC, McMillan AMS, Litvak ME, Read EL, Rocha AV, Rob Elliot J (2006) An eddy covariance mesonet to measure the effect of forest age on land-atmosphere exchange. Glob Change Biol 12(11):2146-2162. doi:10.1111/j.1365-2486. 2006.01251.x

Grace J, Nichol CJ, Disney MI, Lewis P, Quaife T, Bowyer P (2007) Can we measure photosynthesis from space directly, using spectral reflectance and fluorescence? Glob Change Biol 13:1484-1497. doi:10.1111/j.1365-2486.2007.01352.x

Granger CWJ (1969) Investigating causal relations by econometric models and cross-spectral methods. Econometrica 37(3):424-438

Granier A, Ceschia E, Damesin C, Dufrêne E, Epron D, Gross P, Lebaube S, Le Dantec V, Le Goff N, Lemoine D, Lucot E, Ottorini JM, Pontailler JY, Saugier B (2000) The carbon balance of a young Beech forest. Funct Ecol 14(3):312-325. doi: 10.1046/j.1365-2435.2000.00434.x

Gray J (2009) Jim Gray on eScience: A transformed scientific method. In: Hey $\mathrm{T}$, Tansley $\mathrm{S}$, Tolle $\mathrm{K}$ (eds) The fourth paradigm: data-intensive scientific discovery. Microsoft Research, Redmond, p 284

Groenendijk M, Dolman AJ, Ammann C, Arneth A, Cescatti A, Dragoni D, Gash JHC, Gianelle D, Gioli B, Kiely G, Knohl A, Law BE, Lund M, Marcolla B, van der Molen MK, Montagnani L, Moors E, Richardson AD, Roupsard O, Verbeeck H, Wohlfahrt G (2011) Seasonal variation of photosynthetic model parameters and leaf area index from global Fluxnet eddy covariance data. J Geophys Res 116 (G4):G04027. doi:10.1029/ 2011jg001742

Gu L, Meyers T, Pallardy SG, Hanson PJ, Yang B, Heuer M, Hosman KP, Riggs JS, Sluss D, Wullschleger SD (2006) Direct and indirect effects of atmospheric conditions and soil moisture on surface energy partitioning revealed by a prolonged drought at a temperate forest site. J Geophys Res 111 (D16):D16102. doi: 10.1029/2006jd007161

Guerschman JP, Van Dijk AIJM, Mattersdorf G, Beringer J, Hutley LB, Leuning R, Pipunic RC, Sherman BS (2009) Scaling of potential evapotranspiration with MODIS data reproduces flux observations and catchment water balance observations across Australia. J Hydrol 369(1-2):107-119

Hargreaves KJ, Milne R, Cannell MGR (2003) Carbon balance of afforested peatland in Scotland. Forestry 76(3):299-317. doi: 10.1093/forestry/76.3.299

Harrison SP, Prentice IC, Barboni D, Kohfeld KE, Ni J, Sutra J-P (2010) Ecophysiological and bioclimatic foundations for a global plant functional classification. J Veg Sci 21:300-317

Hastings JW, Astrachan L, Sweeney BM (1961) A persistent daily rhythm in photosynthesis. J Gen Physiol 45:69-76. doi:10.1085/ jgp.45.1.69

Havrankova K, Sedlak P (2004) Wind velocity analysis for mountainous site Bily Kriz. Ekologia (Bratislava) 23:46-54
Hays JD, Imbrie J, Shackleton NJ (1976) Variations in the Earth's orbit: pacemaker of the ice ages. Science 194:1121-1132

Herbst M, Rosier PTW, McNeil DD, Harding RJ, Gowing DJ (2008) Seasonal variability of interception evaporation from the canopy of a mixed deciduous forest. Agric For Meteorol 148(11): $1655-1667$

Herrick JD, Thomas RB (2003) Leaf senescence and late-season net photosynthesis of sun and shade leaves of overstory sweetgum (Liquidambar styraciflua) grown in elevated and ambient carbon dioxide concentrations. Tree Physiol 23(2):109-118

Hirano T, Segah H, Harada T, Limin S, June T, Hirata R, Osaki M (2007) Carbon dioxide balance of a tropical peat swamp forest in Kalimantan, Indonesia. Glob Change Biol 13(2):412-425. doi: 10.1111/j.1365-2486.2006.01301.x

Hollinger DY, Goltz SM, Davidson EA, Lee JT, Tu K, Valentine HT (1999) Seasonal patterns and environmental control of carbon dioxide and water vapour exchange in an ecotonal boreal forest. Glob Change Biol 5(8):891-902. doi:10.1046/j.1365-2486. 1999.00281.x

Hunt JR, Baldocchi DD, van Ingen C (2009) Redefining ecological science using data. In: Hey T, Tansley S, Tolle K (eds) The fourth paradigm: data-intensive scientific discovery. Microsoft Research, Redmont, p 284

Kattge J, Díaz S, Lavorel S, Prentice IC, Leadley P, Bönisch G, Garnier E, Westoby M, Reich PB, Wright IJ, Cornelissen JHC, Violle C, Harrison SP, Van Bodegom PM, Reichstein M, Enquist BJ, Soudzilovskaia NA, Ackerly DD, Anand M, Atkin O, Bahn M, Baker TR, Baldocchi D, Bekker R, Blanco CC, Blonder B, Bond WJ, Bradstock R, Bunker DE, Casanoves F, CavenderBares J, Chambers JQ, Chapin Iii FS, Chave J, Coomes D, Cornwell WK, Craine JM, Dobrin BH, Duarte L, Durka W, Elser J, Esser G, Estiarte M, Fagan WF, Fang J, Fernández-Méndez F, Fidelis A, Finegan B, Flores O, Ford H, Frank D, Freschet GT, Fyllas NM, Gallagher RV, Green WA, Gutierrez AG, Hickler T, Higgins SI, Hodgson JG, Jalili A, Jansen S, Joly CA, Kerkhoff AJ, Kirkup D, Kitajima K, Kleyer M, Klotz S, Knops JMH, Kramer K, Kühn I, Kurokawa H, Laughlin D, Lee TD, Leishman M, Lens F, Lenz T, Lewis SL, Lloyd J, Llusiá J, Louault F, Ma S, Mahecha MD, Manning P, Massad T, Medlyn BE, Messier J, Moles AT, Müller SC, Nadrowski K, Naeem S, Niinemets Ü, Nöllert S, Nüske A, Ogaya R, Oleksyn J, Onipchenko VG, Onoda Y, Ordoñez J, Overbeck G, Ozinga WA, Patiño S, Paula S, Pausas JG, Peñuelas J, Phillips OL, Pillar V, Poorter H, Poorter L, Poschlod P, Prinzing A, Proulx R, Rammig A, Reinsch S, Reu B, Sack L, Salgado-Negret B, Sardans J, Shiodera S, Shipley B, Siefert A, Sosinski E, Soussana JF, Swaine E, Swenson N, Thompson K, Thornton P, Waldram M, Weiher E, White M, White S, Wright SJ, Yguel B, Zaehle S, Zanne AE, Wirth C (2011) TRY - a global database of plant traits. Glob Change Biol 17(9):2905-2935. doi:10.1111/j.13652486.2011.02451.x

Knohl A, Schulze E-D, Kolle O, Buchmann N (2003) Large carbon uptake by an unmanaged 250-year-old deciduous forest in Central Germany. Agric For Meteorol 118:151-167

Krinner G, Viovy N, de Noblet-Ducoudré N, Ogée J, Polcher J, Friedlingstein P, Ciais P, Sitch S, Prentice IC (2005) A dynamic global vegetation model for studies of the coupled atmospherebiosphere system. Glob Biogeochem Cycle 19:GB1015. doi: 10.1029/2003GB002199

Kurbatova J, Arneth A, Vygodskaya NN, Kolle O, Varlargin AV, Milyukova IM, Tchebakova NM, Schulze E-D, Lloyd J (2002) Comparative ecosystem-atmosphere exchange of energy and mass in a European Russian and a central Siberian bog I. Interseasonal and interannual variability of energy and latent heat fluxes during the snowfree period. Tellus B 54 (5):497-513. doi:10.1034/j.1600-0889.2002.01354.x 
Kurbatova J, Li C, Varlagin AB, Xiao X, Vygodskaya NN (2008) Modeling carbon dynamics in two adjacent spruce forests with different soil conditions in Russia. Biogeosciences 5:969-980. doi:10.5194/bg-5-969-2008

Lafleur PM, Roulet NT, Bubier JL, Moore TR, Frolking S (2003) Interannual variability in the peatland-atmosphere carbon dioxide exchange at an ombrotrophic bog. Glob Biogeochem Cycle 17:1036. doi:10.1029/2002GB001983

Lagergren F, Lindroth A, Dellwik E, Ibrom A, Lankreijer H, Launiainen S, Mölder M, Kolari P, Pilegaard KIM, Vesala T (2008) Biophysical controls on $\mathrm{CO}_{2}$ fluxes of three Northern forests based on long-term eddy covariance data. Tellus B 60(2):143-152. doi:10.1111/j.1600-0889.2006.00324.x

Lambers H, Chapin FSI, Pons TL (2000) Plant physiological ecology. Springer, New York

Lasslop G, Reichstein M, Papale D, Richardson AD, Arneth A, Barr AG, Stoy PC, Wohlfahrt G (2010) Separation of net ecosystem exchange into assimilation and respiration using a light response curve approach: critical issues and global evaluation Glob Change. Biology 16:187-208

Le Maire G, Davi H, Soudani K, Francois C, Le Dantec V, Dufresne E (2005) Modeling annual production and carbon fluxes of a large managed temperate forest using forest inventories, satellite data and field measurements. Tree Physiol 25(7):859-872. doi: 10.1093/treephys/25.7.859

Lee X, Fuentes JD, Staebler RM, Neumann HH (1999) Long-term observation of the atmospheric exchange of $\mathrm{CO}_{2}$ with a temperate deciduous forest in southern Ontario, Canada. J Geophys Res-Atmos 104 (D13):15975-15984

Lindroth A, Klemedtsson L, Grelle A, Weslien P, Langvall O (2008a) Measurement of net ecosystem exchange, productivity and respiration in three spruce forests in Sweden shows unexpectedly large soil carbon losses. Biogeochemistry 89(1):43-60. doi: 10.1007/s10533-007-9137-8

Lindroth A, Lagergren F, Aurela M, Bjarnadottir B, Christensen T, Dellwik E, Grelle A, Ibrom A, Johansson T, Lankreijer $\mathrm{H}$, Launiainen S, Laurila T, Molder M, Nikinmaa E, Pilegaard KIM, Sigurdsson BD, Vesala T (2008b) Leaf area index is the principal scaling parameter for both gross photosynthesis and ecosystem respiration of Northern deciduous and coniferous forests. Tellus B 60(2):129-142. doi:10.1111/j.1600-0889. 2007.00330.x

Lund M, Lindroth A, Christensen TR, Strom L (2007) Annual $\mathrm{CO}_{2}$ balance of a temperate bog. Tellus B 59:804-811

Marcolla B, Pitacco A, Cescatti A (2003) Canopy architecture and turbulence structure in a coniferous forest. Bound-Layer Meteorol 108(1):39-59. doi:10.1023/a:1023027709805

Matese A, Alberti G, Gioli B, Toscano P, Vaccari FP, Zaldei A (2008) Compact_Eddy: a compact, low consumption remotely controlled eddy covariance logging system. Comput Electron Agric 64(2):343-346

Medlyn BE, Robinson AP, Clement R, McMurtrie R (2005) On the validation of models of forest $\mathrm{CO}_{2}$ exchange using eddy covariance data: some perils and pitfalls. Tree Physiol 25:839-857

Noormets A, Chen J, Crow T (2007) Age-dependent changes in ecosystem carbon fluxes in managed forests in northern Wisconsin, USA. Ecosystems 10(2):187-203. doi: 10.1007/s10021-007-9018-y

Papale D, Reichstein M, Aubinet M, Canfora E, Bernhofer C, Kutsch W, Longdoz B, Rambal S, Valentini R, Vesala T, Yakir D (2006) Towards a standardized processing of net ecosystem exchange measured with eddy covariance technique: algorithms and uncertainty estimation. Biogeosciences 3:571-583

Pavlick R, Drewry DT, Bohn K, Reu B, Kleidon A (2012) The Jena Diversity-Dynamic Global Vegetation Model (JeDi-DGVM): a diverse approach to representing terrestrial biogeography and biogeochemistry based on plant functional tradeoffs. Biogeosci Discuss 9:4627-4726. doi:10.5194/bgd-9-4627-2012

Pilegaard K, Hummelshoj P, Jensen NO, Chen Z (2001) Two years of continuous $\mathrm{CO}_{2}$ eddy-flux measurements over a Danish beech forest. Agric For Meteorol 107(1):29-41

R Development Core Team (2011) R: A Language and Environment for Statistical Computing. R Foundation for Statistical Computing, Vienna

Randerson JT, Hoffman FM, Thornton PE, Mahowald NM, Lindsay K, Lee Y-H, Nevison CD, Doney SC, Bonan G, Stöckli R, Covey C, Running SW, Fung IY (2009) Systematic assessment of terrestrial biogeochemistry in coupled climate-carbon models. Glob Change Biol 15(10):2462-2484. doi:10.1111/j.1365-2486. 2009.01912.x

Rayment MB, Jarvis PG (1999) Seasonal gas exchange of black spruce using an automatic branch bag system. Can J For Res 29(10):1528-1538. doi:10.1139/x99-130

Reich PB, Walters MB, Ellsworth DS (1991) Leaf age and season influence the relationships between leaf nitrogen, leaf mass per area and photosynthesis in maple and oak trees. Plant Cell Environ 14:251-259

Reichstein M, Falge E, Baldocchi D, Papale D, Aubinet M, Berbigier $\mathrm{P}$, Bernhofer C, Buchmann N, Gilmanov TG, Granier A, Grünwald T, Havránková K, Ilvesniemi H, Janous D, Knohl A, Laurila T, Lohila A, Loustau D, Matteucci G, Meyers T, Miglietta F, Ourcival J-M, Pumpanen J, Rambal S, Rotenberg E, Sanz M, Tenhunen J, Seufert G, Vaccari F, Vesala T, Yakier D, Valentini R (2005) On the separation of net ecosystem exchange into assimilation and ecosystem respiration: review and improved algorithm. Glob Change Biol 11:1424-1439

Reichstein M, Stoy PC, Desai AR, Lasslop G, Richardson AD (2012) Partitioning of net fluxes. In: Aubinet M, Vesala T, Papale D (eds) Eddy covariance: A practical guide to measurement and data analysis. Springer, Dordrecht, p 460

Ricciuto DM, King AW, Gu L, Post WM (2008) Estimates of terrestrial carbon cycle model parameters by assimilation of FLUXNET data: do parameter variations cause bias in regional flux estimates? Eos Trans AGU 89 (53):Fall Meet. Suppl., Absttact B54-03

Richardson A, Jenkins J, Braswell B, Hollinger D, Ollinger S, Smith M-L (2007a) Use of digital webcam images to track spring green-up in a deciduous broadleaf forest. Oecologia 152(2):323-334. doi:10.1007/s00442-006-0657-z

Richardson AD, Hollinger DY, Aber JD, Ollinger SV, Braswell BH (2007b) Environmental variation is directly responsible for short- but not long-term variation in forest-atmosphere carbon exchange. Glob Change Biol 13:788-803

Ryu Y, Baldocchi DD, Ma S, Hehn T (2008) Interannual variability of evapotranspiration and energy exchange over an annual grassland in California. J Geophys Res 113:D09104. doi: 10.1029/2007JD009263

Ryu Y, Baldocchi DD, Kobayashi H, van Ingen C, Li J, Black TA, Beringer J, van Gorsel E, Knohl A, Law BE, Roupsard O (2011) Integration of MODIS land and atmosphere products with a coupled-process model to estimate gross primary productivity and evapotranspiration from $1 \mathrm{~km}$ to global scales. Global Biogeochem Cycles 25 (4):GB4017. doi:10.1029/2011gb004053

Sagerfors J, Lindroth A, Grelle A, Klemedtsson L, Weslien P, Nilsson $\mathrm{M}$ (2008) Annual $\mathrm{CO}_{2}$ exchange between a nutrient-poor, minerotrophic, boreal mire and the atmosphere. J Geophys Res 113 (G1):G01001. doi:10.1029/2006jg000306

Saleska SR, Miller SD, Matross DM, Goulden M, Wofsy S, da Rocha HR, de Camargo PB, Crill P, Daube BC, de Freitas HC, Hutyra L, Keller M, Kirchhoff V, Menton M, Munger JW, Pyle EH, Rice AH, Silva H (2003) Carbon in amazon forests: unexpected 
seasonal fluxes and disturbance-induced losses. Science 302:1554-1557

Schaefer K, Schwalm CR, Williams C, Arain MA, Barr A, Chen JM, Davis KJ, Dimitrov D, Hilton TW, Hollinger DY, Humphreys E, Poulter B, Raczka BM, Richardson AD, Sahoo A, Thornton P, Vargas R, Verbeeck H, Anderson R, Baker I, Black TA, Bolstad P, Chen J, Curtis PS, Desai AR, Dietze M, Dragoni D, Gough C, Grant RF, Gu L, Jain A, Kucharik C, Law B, Liu S, Lokipitiya E, Margolis HA, Matamala R, McCaughey JH, Monson R, Munger JW, Oechel W, Peng C, Price DT, Ricciuto D, Riley WJ, Roulet N, Tian H, Tonitto C, Torn M, Weng E, Zhou X (2012) A modeldata comparison of gross primary productivity: results from the North American Carbon Program site synthesis. J Geophys Res 117 (G3):G03010. doi:10.1029/2012jg001960

Schmid HP, Grimmond CSB, Cropley F, Offerle B, Su HB (2000) Measurements of $\mathrm{CO}_{2}$ and energy fluxes over a mixed hardwood forest in the mid-western United States. Agric For Meteorol 103(4):357-374

Schwalm CR, Williams CA, Schaefer K, Anderson R, Arain MA, Baker I, Barr AG, Black TA, Chen G, Chen JM, Ciais P, Davis KJ, Desai AR, Dietze M, Dragoni D, Fischer ML, Flanagan LB, Grant R, Gu L, Hollinger D, Izaurralde RC, Kucharik CJ, Lafleur PM, Law BE, Li L, Li Z, Liu S, Lokupitiya E, Luo Y, Ma S, Margolis H, Matamala R, McCaughey JH, Monson RK, Oechel W, Peng C, Poulter B, Price DT, Riciutto DM, Riley W, Sahoo AK, Sprintsin M, Sun J, Tian H, Tonitto C, Verbeeck H, Verma SB (2010) A model-data intercomparison of $\mathrm{CO}_{2}$ exchange across North America: results from the North American Carbon Program Site Synthesis. J Geophys Res. doi:10.1029/2009J G001229

Sellers PJ, Hall F, Margolis H, Kelly B, Baldocchi DD, Den Hartog G, Cihlar J, Ryan MG, Goodison B, Crill P, Ranson KJ, Lettenmaier DP, Wickland DE (1995) The Boreal EcosystemAtmosphere Study (BOREAS): an overview and early results from the 1994 field year. 76:1549-1577

Sitch S, Smith B, Prentice IC, Arneth A, Bondeau A, Cramer W, Kaplan JO, Levis S, Lucht W, Sykes M, Thonicke K, Venevsky S (2003) Evaluation of ecosystem dynamics, plant geography and terrestrial carbon cycling in the LPJ dynamic global vegetation model. Glob Change Biol 9:161-185

Song C, Katul GG, Oren R, Band LE, Tague CL, Stoy PC, McCarthy HR (2009) Energy, water, and carbon fluxes in a loblolly pine stand: results from uniform and gappy canopy models with comparisons to eddy flux data. J Geophys Res 114:G04021. doi: 10.1029/2009JG000951

Stoy PC, Katul GG, Siqueira MBS, Juang J-Y, Novick KA, Oren R (2006) An evaluation of methods for partitioning eddy covariance-measured net ecosystem exchange into photosynthesis and respiration. Agric For Meteorol 141:2-18

Stoy PC, Richardson AD, Baldocchi DD, Katul GG, Stanovick J, Mahecha MD, Reichstein M, Detto M, Law BE, Wohlfahrt G, Arriga N, Campos J, McCaughey JH, Montagnani L, Paw UKT, Sevanto S, Williams M (2009) Biosphere-atmosphere exchange of $\mathrm{CO}_{2}$ in relation to climate: a cross-biome analysis across multiple time scales. Biogeosciences 6:2297-2312

Suni T, Rinne J, Reissell A, Altimir N, Keronen P, Rannik U, Dal Maso M, Kulmala M, Vesala T (2003) Long-term measurements of surface fluxes above a Scots pine forest in Hyytiala, southern Finland, 1996-2001. Boreal Environ Res 8:287-301

Thornton PE, Law BE, Gholz HL, Clark KL, Falge E, Ellsworth DS, Goldstein AH, Monson RK, Hollinger D, Falk M, Chen J, Sparks JP (2002) Modeling and measuring the effects of disturbance history and climate on carbon and water budgets in evergreen needleleaf forests. Agric For Meteorol 113(1-4):185-222

Thum T, Aalto T, Laurila T, Aurela M, Kolari P, Hari P (2007) Parametrization of two photosynthesis models at the canopy scale in a northern boreal Scots pine forest. Tellus B 59(5):874-890. doi:10.1111/j.1600-0889.2007.00305.x

Tian Y, Woodcock CM, Wang Y, Privette JL, Shabanov NV, Zhou L, Zhang Y, Buermann W, Dong J, Veikkanen B, Hame T, Andersson K, Ozdogan M, Knyazikhin Y, Myneni RB (2002) Multiscale analysis and validation of the MODIS LAI product I. Uncertainty assessment. Remote Sens Environ 83:414-430

Urbanski SP, Barford C, Wofsy S, Kucharik CJ, Pyle EH, Budney J, McKain K, Fitzjarrald D, Czikowsky MJ, Munger JW (2007) Factors controlling $\mathrm{CO}_{2}$ exchange on timescales from hourly to decadal at Harvard Forest. J Geophys Res 112 (G02020). doi: 10.1029/2006JG000293

Valentini R, Matteucci G, Dolman AJ, Schulze ED, Rebmann C, Moors EJ, Granier A, Gross P, Jensen NO, Pilegaard K, Lindroth A, Grelle A, Bernhofer C, Grunwald T, Aubinet M, Ceulemans R, Kowalski AS, Vesala T, Rannik U, Berbigier P, Loustau D, Guomundsson J, Thorgeirsson $\mathrm{H}$, Ibrom A, Morgenstern K, Clement R, Moncrieff J, Montagnani L, Minerbi S, Jarvis PG (2000) Respiration as the main determinant of carbon balance in European forests. Nature 404(6780):861-865

van der Molen MK, van Huissteden J, Parmentier FJW, Petrescu AMR, Dolman AJ, Maximov TC, Kononov AV, Karsanaev SV, Suzdalov DA (2007) The growing season greenhouse gas balance of a continental tundra site in the Indigirka lowlands, NE Siberia. Biogeosciences 4:985-1003. doi:10.5194/bg-4985-2007

van Schaik CP, Terborgh JW, Wright SJ (1993) The phenology of tropical forests: adaptive significance and consequences for primary consumers. Annu Rev Ecol Syst 24:353-377

Verma SB, Baldocchi DD, Anderson DE, Matt DR, Clement RJ (1986) Eddy fluxes of $\mathrm{CO}_{2}$, water vapor, and sensible heat over a deciduous forest. Bound-Layer Meteorol 36(1):71-91. doi: 10.1007/bf00117459

Webb AAR (2003) The physiology of circadian rhythms in plants. New Phytol 160(2):281-303. doi:10.1046/j.1469-8137.2003.008 95. $\mathrm{x}$

Wilkinson M, Eaton EL, Broadmeadow MSJ, Morison JIL (2012) Inter-annual variation of carbon uptake by a plantation oak woodland in south-eastern England. Biogeosci Discuss 9:9667-9710. doi:10.5194/bgd-9-9667-2012

Williams M, Carvalhais N, Hollinger D, Kattge J, Leuning R, Luo Y, Peylin P, Reichstein M, Richardson AD, Santaren D, Stoy PC, Tomelleri I, Trudinger CM, Verbeeck H, Wang YP (2009) Improving land surface models with FLUXNET data. Biogeosciences 6:1341-1359

Wilson KB, Baldocchi DD, Hanson PJ (2000) Spatial and seasonal variability in photosynthetic parameters and their relationship to leaf nitrogen in a deciduous forest. Tree Physiol 20:565-578

Wilson KB, Baldocchi DD, Hanson PJ (2001) Leaf age affects the seasonal pattern of photosynthetic capacity and net ecosystem exchange of carbon in a deciduous forest. Plant Cell Environ 24:571-583

Wofsy SC, Goulden ML, Munger JW, Fan S-M, Bakwin PS, Daube BC, Bassow SL, Bazzaz FA (1993) Net exchange of $\mathrm{CO}_{2}$ in a mid-latitude forest. Science 260(5112):1314-1317. doi:10.1126/ science.260.5112.1314

Wright SJ, van Schaik CP (1994) Light and the phenology of tropical trees. Am Nat 143:192-199

Yuan W, Liu S, Zhou G, Zhou G, Tieszen LL, Baldocchi D, Bernhofer C, Gholz H, Goldstein AH, Goulden ML, Hollinger DY, Hu Y, Law BE, Stoy PC, Vesala T, Wofsy SC (2007) Deriving a light use efficiency model from eddy covariance flux data for predicting daily gross primary production across biomes. Agric For Meteorol 143(3-4):189-207 